\title{
Türk Eğitim Sisteminde Değer Arayışı: Yenilenen (2017) İlköğretim Programları Hangi Değerleri Kazandırıyor?
}

\section{The Quest for Value in Turkish Education System: What kind of values are gained through Turkey's renewed Primary Education Curriculum?}

\author{
Mehmet KART, Sorumlu Yazar, Öğr. Gör. \\ Kırşehir Ahi Evran Üniversitesi, Sağlık Bilimleri Fakültesi, Kırşehir/Türkiye. \\ mehmetkartt@gmail.com \\ https://orcid.org/0000-0003-1790-1270
}

Hüseyin ŞIMŞEK, Prof. Dr.

Ahi Evran Üniversitesi, Eğitim Fakültesi, Kırşehir/Türkiye.

husimsek@hotmail.com

https://orcid.org/0000-0001-7455-3706

ISSN: 1303-880X

e-ISSN: 2667-7504

http://ded.dem.org.tr

Makale Türü / Article Type:

Araştırma Makalesi / Research Article

Geliş Tarihi / Received Date: 24.09.2019

Kabul Tarihi / Accepted Date: 15.07. 2020

Yayın Tarihi / Published Date: 25.12.2020

Tr/En: $\operatorname{Tr}$

Intihal / Plagiarism: Bu makale, en az iki hakem tarafindan incelendi ve intihal içermediği teyit edildi. / This article has been reviewed by at least two referees and scanned via a plagiarism software.
Atıf/Citation: Kart. M. \& Şimşek, H. (2020). Türk eğitim sisteminde değer arayışı: Yenilenen (2017) ilköğretim programları hangi değerleri kazandırıyor? Değerler Eğitimi Dergisi,18 (40), s.9-44.

https://doi.org/10.34234/ded.623787 
Öz: Bu çalışmada, 2017 yılında yenilenen ilköğretim programlarında hangi değerlerin yer aldığı incelenmiştir. Nitel desende durum çalışması olarak tasarlanan araştırmada içerik analizi tekniği kullanılmıştır. Araştırma sonucunda, ilköğretim programlarının değer anlayışının iyi insan iyi vatandaş beklentisi üzerine temellendirildiği anlaşılmıştır. İlköğretim programlarının gerek açıklama kısmında gerekse kazanımlarında değerlere yer verilmiş, değerlerin bireyin gelişimindeki önemi üzerinde durulmuştur. İlköğretim programlarında bireyin çok yönlü gelişimine özel vurgu yapılmış, değerlerin birey gelişimindeki önemine değinilmiştir. Araştırma sonucunda elde edilen bulgulara göre ilköğretim düzeyindeki 20 dersin öğretim programında yer alan tüm kazanımların \%11,83’ü duyuşsal alana hitap eden ve değer içeren kazanımlardan oluşmaktadır. İlköğretim programlarının tamamında 65 farklı değere yer verilmekte olup en fazla önemsenen değer 92 defa tekrarlanan sorumluluk değeridir. Sorumluluk değerini sirasıyla saygı (38), sağlı̆̆a duyarlılık (37), adalet (26), kültürel mirasa duyarlılık (25) ve çalışkanlık (25) değerleri takip etmektedir. Bu değerler Millî Eğitim Bakanlığının önemsediği kök değerler ile belirli ölçüde örtüşmektedir. Değer içeren kazanımın en fazla olduğu programlar ise Oyun ve Fiziki Etkinlikler, Beden Eğitimi ve Hukuk ve Adalet programlarıdır. Buna karşın Türkçe ve İngilizce programlarında değer içeren herhangi bir kazanım bulunamamıştır. İlköğretim programlarında yer alan değerler, dini-ahlaki, bireysel, toplumsal, millî, demokratik, bilimsel, ekonomik, çevresel ve estetik olmak üzere 9 farklı değer kategorisi altında toplanarak sınıflandırılmıştır.

Anahtar Kelimeler: Değerler, Değer eğitimi, İlköğretim, Kazanım, Program.

$\&$

Abstract: This study examines the values covered in Turkey's renewed primary education curricula in 2017. Qualitative research design, including content analysis is employed for the purpose of the analysis. At the end of the analysis, it is clearly understood that the value perception in the curriculum is based on bringing up an accountable citizen and a benevolent individual. Emphasizing the importance of value in the self-formation of the individuals, reference to values are done both in the introduction and in skill acquisition part of the programe. Especially the multi-dimensional development of an individual is emphasized and the importance of the values in the formation of the individuals is underlined in the curriculum. According to findings, $11.83 \%$ of all the intended learning outcomes of 20 courses at the primary level are related to the affective domain. In the entire primary school level curriculum, 65 different 
values are covered and the most emphasized one is considered as "responsibility" which is stressed 92 times throughout the curriculum. Following the value of Responsibility come values of; Respect (38 times), sensitivity for Health (37 times), Justice (26 times) sensitivity for Cultural Heritage (25 times), and Diligence (25 times). These values noticeably coincide with the core values covered by The Ministry of National Education. The Curricula with the highest value based contents are found to be; Game-Physical Activities, Physical Education, and Law-Justice curricula. However, in the Turkish and English curricula there are no intended learning outcomes related to values. The values in the Primary Curriculum are combined and classified in nine different categories namely; religious-moral, individual, social, national, democratic, scientific, economic, environmental, and aesthetic.

Keywords: Values, Value education, Primary education, Learning outcomes, Curriculum.

(The Extended Abstract is at the end of the article)

\section{Giriş}

Eğitim, insan yetiştirmenin temel vasıtalarından biridir. Ancak insan yetiştirme bir politika işidir. Bu nedenle eğitim politikasının omurgasını nasıl bir insan yetiş̧irileceği sorusu oluşturmaktadır. Eğitim politikasının hayata geçirilmesinde ise eğitim sistemiyle birlikte müfredat ön plana çıkmaktadır. Müfredat aracılığıyla da yetiştirilmesi hedeflenen insanın hangi değerlerle donatılacağ belirlenmektedir. Geçmişte olduğu gibi günümüzde de eğitim sistemlerinin temel arayışı değerler üzerine yoğunlaşmaktadır. Zira insan yetiştirmede bilgi ve beceriler yanında değerler hayati öneme sahiptir. Nitelikli insan yetiştirmenin ancak değerler ile mümkün olacağı düşüncesi eğitim sitemlerini çeşitli arayışlara itmektedir.

Değerlerin eğitim yoluyla kazandırılmasında iki aşamalı bir uygulama gerekmektedir. Bu aşamalardan ilki; eğitim amaçlarının belirlendiği müfredat geliştirme çalışmaları, diğeri ise belirlenen müfredata uygun eğitim faaliyetleridir. Müfredat geliştirme, eğitim sistemlerinin oldukça kapsamlı ve zor konularından biridir. Zira geliştirilecek müfredatın neleri kapsayacağı her zaman tartışma konusu olmuştur. Bu süreçte müfredata yön veren temel felsefenin ne olacağı ve eğitim yoluyla bireylere hangi değerlerin kazandırılacağına karar verilmesi gerekmektedir. Günümüzde değerler eğitimi şeklinde kavramsallaştırılan bu konu 
esasen yeni değildir. Kökleri eğitimin tarihi kadar eski olan değerler eğitimi, karakter eğitimi, ahlak eğitimi ve din eğitimi gibi adlandırmalarla kullanılmıştır (Kuzu, 2015, s.15). Geçmişteki programlarda ahlak eğitimi ve karakter eğitimi şeklinde yer alan değer kazandırma çabalarının bugünkü karşılığı değerler eğitimi kavramıdır (Zengin ve Arslan İçöz, 2018, s.341).

Değerler eğitimi, bireylerin kimlik ve kişilik kazanmalarında en hayati konulardan biridir. Bireylere sistematik bir şekilde duyuşsal davranış örüntülerinin kazandırılabilmesi ancak eğitim programları ile mümkün olabilmektedir. İnsan ve toplum ilişkilerinde yaşanan sorunlar, değerler eğitimini daha popüler bir konu haline getirmiştir.

Türkiye'de belirli bir dönem ihmal edilen değer eğitimi, 2005 yılında yeniden gündeme gelmiş; özellikle sosyal bilgiler dersi öğretim programı sayesinde üzerinde konuşulmaya başlanmıştır. Kapsamlı bir müfredat değişikliği gerçekleşen 2005 y1lında yenilenen din kültürü ve ahlak bilgisi öğretim programlarında din eğitimi- değerler eğitimi değişiklikleriyle beraber öğretim programlarında daha belirgin bir hale gelmiştir (Çelik, 2010, s.2; Kaymakcan ve Meydan, 2011, s.30; Yaylacı ve Beldağ, 2018, s.140).

Türkiye'de değerlerin eğitim programlarında yoğun biçimde yer alması 2017 yılında yapılan kapsamlı program geliştirme sonrasında mümkün olabilmiştir. Millî Eğitim Bakanlığı (MEB) tarafından 18 Temmuz 2017 tarihinde yapılan basın açıklamasında değerler eğitiminin tüm öğretim kademelerinde yaygınlaştırılacağı, daha sistemli bir şekilde uygulanacağı ve öğretim programlarında ayrı bir başlık altında ele alınacağı vurgulanmıştır (Talim ve Terbiye Kurulu Başkanlığı [TTKB], 2017).

Değerlerin kalıcılığı, aktarım ve tekrar yoluyla sağlanabilmektedir. Bu durum, değerlerin yaşatılmasında eğitim ve kültürün önemini ortaya koymaktadır. Değerlerin aktarımında en elverişli araçlardan birisi kuşkusuz eğitimdir. Bu yüzden değerler ve eğitim arasında sağlam ve dinamik bir ilişki bulunmaktadır. Değerlerin değişimi, eğitim sistemine yansımakta ve öğretim uygulamalarında değişime yol açmaktadır. Bu yüzden bir eğitim sisteminin benimsediği değerlerin neler olduğu, formel ve resmî kaynaklarında aranmalıdır. Bu kaynakların başında öğretim programları gelmektedir. Öğretim programları, hangi değerlerin esas alınacağını, başka bir ifade ile hangi değerlerin kazandırılacağını belirlemektedir. Bu yüzden bir eğitim sisteminin öğrencilere hangi değerleri kazandırdığı, ancak öğretim programlarına bakılarak anlaşılmaktadır. 
Değerler eğitiminin öğretim programlarına ne derecede yansıdığı konusu bu araştırmanın temel çıkış noktasını oluşturmaktadır. Bu maksatla, alanyazında öğretim programlarını değerler açısından ele alan çalışmalar incelendiğinde genellikle bir öğretim kademesinin odağa alındığı ve tek bir ders üzerinde araştırmalar yapıldığı görülmektedir (Aktan ve Kılıç, 2015; Baş, 2017; Çekin, 2012; Demir ve Demirhan İșcan, 2007; Gömleksiz ve Cüro, 2011; İdi Tulumcu ve Tulumcu, 2015; Yaşaroğlu, 2018). Ancak, çeşitli öğretim kademelerinde yer alan derslerin tamamını ele alan kapsamlı çalışmalar olmadığından değerlerin Türkiye'deki okul programlarına ne ölçüde yansıdığı hakkında kanaat oluşturmak oldukça güçtür.

$\mathrm{Bu}$ araştırma, ilköğretim kademesinde yer alan 20 dersin öğretim programının tamamını ele alması, değerlerin öğretim kademelerine ve derslere göre nasıl bir dağılım gösterdiğini incelemesi açısından önemli görülmektedir. Bu çalışmada elde edilen bulguların, başta eğitim politikacılarına, değerler eğitimi konusunda araştırma yapacak bilim insanlarına ve tabi ki değerlerin kazandırılmasında hayati öneme sahip olan öğretmenler için faydalı olması ümit edilmektedir.

\section{Araştırmanın Amacı}

Yukarıdaki kuramsal açıklamalar ışığında bu çalışmanın amacı, Türk Eğitim Sisteminde değer arayışının bir örneği olarak 2017 y1lında yenilenen İlköğretim Programlarında öğrencilere kazandırılmak istenen temel değerlerin neler olduğunu ortaya koymaktır. Bu amaç doğrultusunda aşağıdaki sorulara yanıt aranmıştır:

1. İlköğretim programlarının değer anlayışı nedir?

2. İlköğretim programlarında yer alan değer kazanımlarının oransal dağılımı nedir?

3. İlköğretim düzeyindeki derslerin öğretim programlarında yer alan değerler nelerdir?

4. İlköğretim programlarında yer alan değerlerin tekrarlanma sıklıkları ve ilişkili oldukları değer kategorileri nelerdir?

5. İlköğretim programlarında yer alan değerlerin derslere göre yaygınlık durumu nasıldır?

6. İlköğretim programlarında sık tekrarlanan değerler ile kök değerlerin nasıl bir ilişki vardır? 


\section{Yöntem}

\section{Araştırmanın Deseni}

Öğretim programlarında yer alan değerlerin tespit edilmesini amaçlayan bu araştırma, nitel desende tasarlanmış olup, bir durum çalışması özelliği taşımaktadır. Herhangi bir durumun ayrıntılarını tanımlamak, açıklamak ve değerlendirmek amacıyla bu yönteme başvurulmaktadır (Gall, Gall ve Borg, 2007). Durum çalışması, bir olayın, ortamın, öğretim programının, sosyal toplulukların ya da birbiri ile bağlantılı sistemlerin betimlendiği ve incelendiği bir araştırma desenidir (McMillan, 2012; Merriam, 2018). Durum çaşılması, bir durumun ya da olayın derinlemesine ele alınmasını mümkün kılmaktadır (Davey, 2009). İlköğretim programlarının detaylı bir şekilde incelendiği bu çalışmada, belirlenen durum programların kazanımlarında yer alan değerlerin neler olduğunun ortaya konulmasıdır.

Doğası gereği durum çalışmalarında nicel ve nitel veriler birlikte kullanılabilir. Durum çalışmasının nicel ve nitel verileri bir araya getirerek kullanılmasına imkân sunması, durum çalışmasını güçlü bir yöntem haline getirmektedir (Yin, 2003). Çalışmada belirlenen durumun net bir şekilde ortaya konulabilmesi ve açıklanabilmesi için araştırma tasarımında nicel ve nitel veriler birlikte sunulmaya ve yorumlanmaya çalışılmıştır.

\section{Kaynakların Toplanması}

Araştırmanın temel verileri, Millî Eğitim Bakanlığı (MEB) tarafından yayınlanan ilköğretim düzeyindeki tüm derslere ait öğretim programlarıdır. Çalışmaya kaynak teşkil eden öğretim programları http://mufredat.meb.gov.tr/Programlar. aspx adresindeki ilköğretim başlığ altından elektornik ortamda elde edilmiştir. Derslerin seçilmesi konusunda özel bir ayrım yapılmadan bütüncül bir bakış açısı geliştirilebilmesi amacıyla belirtilen sitede yer alan tüm programlar tek tek indirilerek incelenmiştir. Çalışma kapsamında ele alınan programlara ilişkin açıklayıcı tablo aşağıda yer almaktadır: 
Tablo 1: Çalışma Kapsamında İncelenen İlköğretim Derslerine İlişkin Bilgiler

\begin{tabular}{|c|c|c|c|c|c|c|c|c|c|}
\hline \multirow{3}{*}{ Dersler } & & \multicolumn{8}{|c|}{ SINIFLAR } \\
\hline & & \multicolumn{4}{|c|}{ İLKOKUL } & \multicolumn{4}{|c|}{ ORTAOKUL } \\
\hline & & 1 & 2 & 3 & 4 & 5 & 6 & 7 & 8 \\
\hline \multirow{15}{*}{ 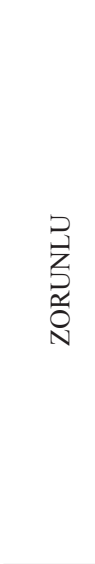 } & Türkçe & $\mathrm{X}$ & $\mathrm{X}$ & $\mathrm{X}$ & $\mathrm{X}$ & $\mathrm{X}$ & $\mathrm{X}$ & $\mathrm{X}$ & $\mathrm{X}$ \\
\hline & Matematik & $\mathrm{X}$ & $\mathrm{X}$ & $\mathrm{X}$ & $\mathrm{X}$ & $\mathrm{X}$ & $\mathrm{X}$ & $\mathrm{X}$ & $\mathrm{X}$ \\
\hline & Hayat Bilgisi & $\mathrm{X}$ & $\mathrm{X}$ & $\mathrm{X}$ & & & & & \\
\hline & Fen Bilimleri & & & $\mathrm{X}$ & $\mathrm{X}$ & $\mathrm{X}$ & $\mathrm{X}$ & $\mathrm{X}$ & $\mathrm{X}$ \\
\hline & Sosyal Bilgiler & & & & $\mathrm{X}$ & $\mathrm{X}$ & $\mathrm{X}$ & $\mathrm{X}$ & \\
\hline & İnkılap Tarihi ve Atatürkçülük & & & & & & & & $\mathrm{X}$ \\
\hline & İngilizce & & $\mathrm{X}$ & $\mathrm{X}$ & $\mathrm{X}$ & $\mathrm{X}$ & $\mathrm{X}$ & $\mathrm{X}$ & $\mathrm{X}$ \\
\hline & Görsel Sanatlar & $\mathrm{X}$ & $\mathrm{X}$ & $\mathrm{X}$ & $\mathrm{X}$ & $\mathrm{X}$ & $\mathrm{X}$ & $\mathrm{X}$ & $\mathrm{X}$ \\
\hline & Müzik & $\mathrm{X}$ & $\mathrm{X}$ & $\mathrm{X}$ & $\mathrm{X}$ & $\mathrm{X}$ & $\mathrm{X}$ & $\mathrm{X}$ & $\mathrm{X}$ \\
\hline & Oyun ve Fiziki Etkinlikler & $\mathrm{X}$ & $\mathrm{X}$ & $\mathrm{X}$ & $\mathrm{X}$ & & & & \\
\hline & Beden Eğitimi & & & & & $\mathrm{X}$ & $\mathrm{X}$ & $\mathrm{X}$ & $\mathrm{X}$ \\
\hline & Teknoloji ve Tasarım & & & & & & & $\mathrm{X}$ & $\mathrm{X}$ \\
\hline & Trafik Güvenliği & & & & $\mathrm{X}$ & & & & \\
\hline & Bilişim Teknolojileri ve Yazılım & & & & & $\mathrm{X}$ & $\mathrm{X}$ & & \\
\hline & İnsan Hakları & & & & $\mathrm{X}$ & & & & \\
\hline \multirow{6}{*}{ 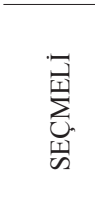 } & Peygamberimizin Hayatı & & & & & $\mathrm{X}$ & $\mathrm{X}$ & $\mathrm{X}$ & $\mathrm{X}$ \\
\hline & Temel Dini Bilgiler (İslam 1) & & & & & $\mathrm{X}$ & $\mathrm{X}$ & $\mathrm{X}$ & $\mathrm{X}$ \\
\hline & Temel Dini Bilgiler (İslam 2) & & & & & $\mathrm{X}$ & $\mathrm{X}$ & $\mathrm{X}$ & $\mathrm{X}$ \\
\hline & İHO Temel Dini Bilgiler & & & & & $\mathrm{X}$ & $\mathrm{X}$ & $\mathrm{X}$ & $\mathrm{X}$ \\
\hline & Şehrimiz & & & & & $\mathrm{X}$ & $\mathrm{X}$ & $\mathrm{X}$ & $\mathrm{X}$ \\
\hline & Hukuk ve Adalet & & & & & & $\mathrm{X}$ & $\mathrm{X}$ & $\mathrm{X}$ \\
\hline
\end{tabular}

Yukarıdaki tablo incelendiğinde araştırma kapsamında incelenen 20 dersin 14 tanesinin zorunlu, 6 tanesinin de seçmeli ders olduğu anlaşılmaktadır. Tabloda ayrıca hangi derslerin hangi sınıf düzeyinde okutulduğu da görülmektedir. Örneğin; Türkçe dersi tüm sınıf düzeylerinde okutulurken, trafik güvenliği ve insan hakları dersleri yalnızca dördüncü sınıf düzeyinde okutulmaktadır. Bununla birlikte, peygamberimizin hayat, temel dini bilgiler, şehrimiz ve hukuk-adalet dersleri ise yalnızca ortaokul düzeyinde okutulan derslerdir. Hayat bilgisi, oyun ve fiziki etkinlikler, trafik güvenliği ve insan hakları dersleri ise ilkokul düzeyinde okutulan derslerdir.

Tablo 1' de detayları verilen ve çalışma kapsamında incelenen öğretim programlarına ait veriler, nitel araştırma yöntemlerinden "doküman analizi” tekniği ile elde edilmiştir. Doküman analizi tekniği ile araştırılması hedeflenen olgu ya da olgular hakkında bilgi içeren yazılı materyallerin analizi yapılmaktadır (Karasar, 2009, s.183). Dokümanlar, nitel araştırmalarda etkili bir şekilde kullanılması gereken önemli bilgi kaynaklarıdır. Diğer nitel veri toplama yöntemleriyle kıyaslandığında "denek" veya "katılımcı tepkiselliği” sorununa yol açmaz. Ayrıca, araştırmacıya kazandırdığı zaman ve para tasarrufu avantajından ötürü çalışmanın daha etkili biçimde gerçekleştirilmesini sağlar (Yıldırım ve Şimşek, 2013, ss. 218-220). 


\section{Verilerin Analizi}

Millî Eğitim Bakanlığı tarafından 2017 y1lında yenilenen ilköğretim programlar1, çalışmanın amaçları doğrultusunda incelenmiştir. Araştırma verilerinin analizinde içerik analizi tekniği kullanılmıştır. Bu çerçevede öğretim programlarında yer alan değerlerle ilgili olduğu düşünülen kelime, cümle ya da paragraf biçiminde yer alan ifadeler içerik analiz birimi olarak kabul edilmiş, programların genelinde ve kazanımlarında değer ifadeleri aranmıştır. Çalışmanın verimliliği ve analiz sürecinin kolaylaştırılması maksadıyla her bir dersin öğretim programı ayrıntılı biçimde incelenmiş ve sınıf-kazanım numaraları eşleştirilmiştir. Benzer anlam içeren ancak farklı biçimde ifade edilen değerler gruplandırılarak bütünlük sağlanmaya çalışılmıştır.

$\mathrm{Bu}$ bağlamda, ilk olarak programların açıklamalar kısmında belirtilen değerler ortaya konulmuş, daha sonra programların kazanımlarında yer alan değerler saptanarak tablo üzerinde belirtilmiştir. Tabloda ilköğretim programlarının kazanımlarında kaç farklı değerin yer aldığı bilgisi verilmiştir. Tablo oluşturulurken öncelikle ilköğretim programlarında yer alan kazanımlar üzerinde kodlama yapılmıştır. Kodlamayla birlikte hem değer içeren kazanımlar belirlenmiş hem de bu kazanımlarda hangi değerlerin işaret edildiği bulunmaya çalışılmıştır. Araştırmacılar tarafindan yapılan kodlama sonrasında ilköğretim programlarının kazanımlarında yer alan değerlerin ilişkili oluğu değer kategorileri belirlenmiştir. Gerek kazanımlarda geçen değer ifadelerinin tespiti gerekse bu değerlerin ilişkili olduğu kategorilerin belirlenmesi sürecinde kodlama güvenirliği metoduna başvurulmuş, 5 uzmana kazanımlardan çıkarılan değerlerin hangi değer kategorisinde yer aldığına ilişkin görüş sorulmuştur. Böylece uzman görüşlerinde uzlaşma aranmıştır. Kodlayıcı güvenirliği çalışması kapsamında, araştırmacıların her biri tarafından ayrı ayrı yapılan kodlamalar karşılaştırılarak aralarındaki uyum aranmıştır. Miles ve Huberman'ın (1994, s.64) formülü [Güvenirlik= görüş birliği/görüş birliği+görüş ayrıllı̆ 1 X 100] kullanılarak yapılan hesaplamalarda kodlayıcılar arasındaki uyum oranı \%93 olarak belirlenmiştir. Güvenirlik hesaplama oranının \%90 ve üstü olması, araştırma için güvenilir kabul edilmektedir. Hesaplanan sonuç araştırma için güvenilir kabul edilmiştir. $\mathrm{Bu}$ süreç sonucunda öğretim programlarında tespit edilen değerlere ilişkin bulgular aşağıda sunulmuştur. 


\section{Bulgular}

Araştırma kapsamında, 2017 yılında yenilenen ilköğretim programları incelenmiş, programların değer anlayışının iyi insan iyi vatandaş beklentisi üzerine temellendirildiği görülmüştür. Buna göre iyi insan ve iyi vatandaş olmak; gerekli bilgi, beceri, tutum, davranış ve alışkanlıkların kazanılması ile gerçekleşebilecektir. Yenilenen programların temel anlayışı, eğitimin değerlerle şekillenmiş bir etkinlik olarak görülmesi şeklindedir. Ayrıca, yenilenen programlarda değer eğitiminin amaçları; öğrencilerin sağlıklı, tutarlı ve dengeli bir kişilik geliştirmelerini sağlama şeklinde özetlenmiştir (Türkçe Dersi Öğretim Programı, 2017, s.7).

Yenilenen ilköğretim programlarında bireyin çok yönlü gelişimine özel vurgu yapılmış, değerlerin birey gelişimindeki önemi üzerinde durulmuştur. Kazandırılacak değerlerin, bireyin sağlıklı ve dengeli biçimde gelişmesine katkı sağlayacağı ifade edilmiştir. Programların giriş kısmında, Türk Millî Eğitim Sistemi'nin temel hedefinin öğrencilerin sağlıklı, mutlu bir şekilde hayata hazırlanması, iyi insan ve iyi vatandaş olmalarını sağlayacak bilgi, beceri, değer, tutum, davranış ve alışkanlıklarla donatılması olduğu vurgulanmıştır. Ayrıca değerlerin yeni nesillere aktarılmasının kültürel devamlılığın sağlanması ve eğitim hedeflerine ulaşılması açısından önemli olduğuna işaret edilmiştir (Bilişim Teknolojileri ve Yazılım Dersi Öğretim Programı, 2017, s.8).

İlköğretim programlarında insan ilişkilerinin değerler temelinde düzenlendiğine vurgu yapılarak millî, manevî ve evrensel değerlerin öğrencilere tanıtılması, benimsetilmesi ve bunların içselleştirerek davranışa dönüştürülmesinde ailenin, toplumun ve medyanın yanı sıra öğretim programlarının da önemli bir etkisinin olduğu belirtilmiştir (Oyun ve Fiziki Etkinlikler Dersi Öğretim Programı, 2017, s.8). Öğretim programlarının kazanımlarında değer ifadelerinin yer aldığı belirtilerek, bunların öğrencilere hissettirilmesi ve yaşantı hâle getirilmesi istenmektedir. Bu yaklaşım, kazanımların gerçekleştirilmesiyle değerlerin de öğrencilere kazandırılacağı öngörüsüne dayanmaktadır. Ancak programlarda bazı çekincelere de işaret edilmiştir. Buna göre öğretim programının uygulay1cısı olan öğretmenin değerler eğitimine ilişkin farkındalığının yanı sıra yeterliliği, becerisi ve model olabilme özelliği bu süreçte büyük önem taşımaktadır (Görsel Sanatlar Dersi Öğretim Program1, 2017, s.8).

İlköğretim programlarında, değerlerin nasıl yer aldığını gösteren önemli bir şemaya yer verilmiştir. Aşağıda örnek olması bakımında Hayat Bilgisi Dersi Öğretim Programının Organizasyon Yapısını gösteren şemaya yer verilmiş̧tir (Hayat Bilgisi Dersi Öğretim Program1, 2017): 


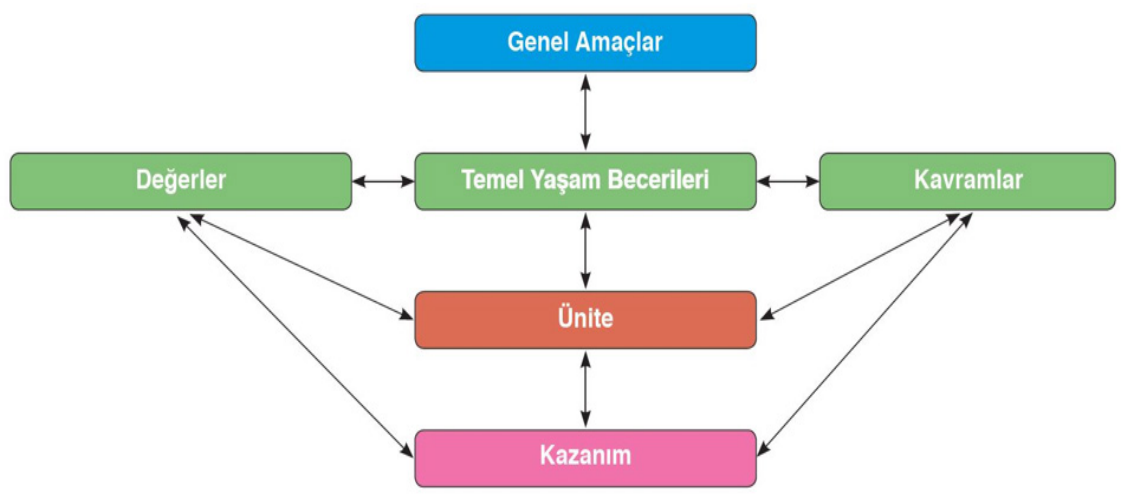

Şekil 1. İlköğretim programlarının organizasyonu

Öğretim programlarının organizasyon yapısını gösteren şema incelendiğinde, yenilenen öğretim programlarında değerlerin programın ana omurgası içerisinde yer aldığ 1 görülmektedir. Programların organizasyon şemasında değerlerin ayrı bir bölüm olarak yer alması, konuya verilen önemin bir göstergesi olarak kabul edilebilir. Öğretim programına ait organizasyon şemasında da görüleceği üzere, değerler temel yaşam becerileri ve kavramlar gibi eğitimin temel öncelikleri arasında yer almaktadır. Bu şematik yaklaşım ve önemine işaret eden ifadelerin yanında, ilköğretim programlarında değerlerin nasıl yer aldığı ayrıca incelenmiş ve aşağıdaki bulgular elde edilmiştir.

Millî Eğitim Bakanlığı tarafından Temmuz 2017 tarihinde gerçekleştirilen basın toplantısında sunulan "Müfredatta Yenileme ve Değişiklik Çalışmalarımız Üzerine" isimli dokümanda, önceki öğretim programlarından farklı olarak, değerler eğitimi konusunun yenilenen programlarının ana odağı olduğu ifade edilmiştir. Ayrıca kapsamlı bir alanyazın taraması sonucunda, disiplin alanlarının her birinde kazanımlarla ilişkilendirmenin yapıldığı, böylece kazandırılması beklenen millî, manevî ve evrensel değerlerin 10 (on) ana başlık altında toplandığı belirtilmiştir (TTKB, 2017, s.7).

Öğretim programlarının giriş kısmına eklenen "Değer(ler) Eğitimi” başlığı altında, değerlerin programlarda yer alma nedenleri, nasıl yer aldığı, öğrenme-öğretme sürecinde öğrencilere nasıl aktarılabileceği, hangi öğretim yöntem ve tekniklerin kullanılması gerektiğine dair açıklamalara yer verilmiş̧ir. Ayrıca, öğretim programlarında yer alan ve öğrencilere kazandırılması beklenen kök değerlerden de bahsedilmektedir. İlköğretim programlarında yer alan kök değerler şunlardır: Adalet, dostluk, dürüstlük, öz denetim, sabır, sayg1, sevgi, so- 
rumluluk, vatanseverlik ve yardımseverlik (Hayat Bilgisi Dersi Öğretim Program1, 2017, s.8).

Yenilenen ilköğretim programları incelendiğinde, değerlerin derslere göre farklılık gösterdiği anlaşılmaktadır. Bazı derslerin öğretim programlarında, değerlerin önemi ve ilgili ders ile ilişkisi açıklanırken (Bilişim Teknolojileri ve Yazılım Dersi Öğretim Programı, 2017, ss.8-9), bazılarında ise değerler dizisi listesi verilmiş ve değerlerin kazandırılması sürecinde nasıl bir yol izlenmesi gerektiği anlatılmıştır (Matematik Dersi Öğretim Programı, 2017, s.14). Ders temelinde bakıldığında, ilkokul seviyesindeki derslerin öğretim programlarında en az 8, en fazla 34 değer yer alırken, ortaokul düzeyindeki derslerin öğretim programlarında ise bu sayı 8-38 arasında değişmektedir (Öğretim Programı Taslaklarında, 2017).

Yukarıdaki tespitler 1şı̆̆ında, yenilenen ilköğretim programlarında yer alan kök değerler ve bu değerlere ilişkin tutum ve davranışları gösteren bir tablo aşağıda verilmiştir (TTKB, 2017, s.24)

\begin{tabular}{ll}
\hline Tablo 2: 2017 Programlarında Yer Alan Kök Değerler ve Bu Değerlere İlişkin Tutum ve Davranışlar \\
\hline Değerler & Değerlere İlişkin Tutum ve Davranışlar \\
\hline Adalet & Adil olma, eşit davranma, paylaşma \\
\hline Dostluk & $\begin{array}{l}\text { Diğerkâmlık, güven duyma, anlayışlı olma, dayanışma, sadık olma, vefalı olma, } \\
\text { yardımlaşma }\end{array}$ \\
\hline Dürüstlük & Açık ve anlaşıılır olma, doğru sözlü olma, güvenilir olma, sözünde durma... \\
\hline Öz denetim & $\begin{array}{l}\text { Davranışlarını kontrol etme, davranışlarının sorumluluğunu üstlenme, öz güven } \\
\text { sahibi olma, gerektiğinde özür dileme }\end{array}$ \\
\hline Sabır & Azimli olma, tahammül etme, beklemeyi bilme \\
\hline Saygı & $\begin{array}{l}\text { Alçakgönüllü olma, başkalarına kendine davranılmasını istediği şekilde davranma, } \\
\text { diğer insanların kişiliklerine değer verme, muhatabının konumunu, özelliklerini ve } \\
\text { durumunu gözetme }\end{array}$ \\
\hline Sevgi & $\begin{array}{l}\text { Aile birliğine önem verme, fedakârlık yapma, güven duyma, merhametli olma, vefalı } \\
\text { olma }\end{array}$ \\
\hline Sorumluluk & $\begin{array}{l}\text { Kendine, çevresine, vatanına, ailesine karşı sorumlu olma; sözünde durma, tutarlı ve } \\
\text { güvenilir olma, davranışlarının sonuçlarını üstlenme }\end{array}$ \\
\hline Vatanseverlik & $\begin{array}{l}\text { Çalışkan olma, dayanışma, kurallara ve kanunlara uyma, sadık olma, tarihsel ve } \\
\text { doğal mirasa duyarlı olma, toplumu önemseme }\end{array}$ \\
\hline $\begin{array}{l}\text { Yardımse- } \\
\text { verlik }\end{array}$ & \begin{tabular}{l} 
Cömert olma, iş birliği yapma, merhametli olma, misafirperver olma, paylaşma \\
\hline
\end{tabular}
\end{tabular}

Kök değerler ve bunlara ilişkin davranışları gösteren tablo incelendiğinde, değerlerin bireylerin kişisel yaşantılarında, sosyal ortamlarında ve insan ilişkilerinde nasıl bir tutuma sahip olmalarına yönelik olduğu anlaşılmaktadır. Kök değerler genel olarak sınıflandırıldı̆̆ında ise sosyal (adalet, dostluk, dürüstlük, sayg1, yardımseverlik), kişisel (öz denetim, sabır, sorumluluk, sevgi) ve millî (vatanseverlik) değerler kategorilerinde oldukları görülmektedir. 


\section{İlköğretim Programlarında Yer Alan Değer Kazanımları- nın Oransal Dağılımı}

Bu çalışma kapsamında, ilköğretim düzeyindeki derslere ait 20 dersin öğretim programı ayrı ayrı incelenmiştir. Aşağıda tüm derslerin kazanımlarını, değer içeren kazanımlarını ve değerlerin program düzeyindeki kazanımlara oranlarını gösteren bir tablo verilmiştir.

Tablo 3: İlköğretim Programlarında Yer Alan Değer Kazanımlarının Toplam Kazanımlara Oranı

\begin{tabular}{|c|c|c|c|}
\hline Dersler & $\begin{array}{l}\text { Kazanım } \\
\text { Sayısı }\end{array}$ & $\begin{array}{l}\text { Değer İçeren Kazanım } \\
\text { Sayısı }\end{array}$ & $\begin{array}{l}\text { Program Düzeyinde } \\
\text { Oran }\end{array}$ \\
\hline Oyun ve Fiziki Etkinlikler & 106 & 72 & $\% 67,92$ \\
\hline Beden Eğitimi & 122 & 82 & $\% 67,21$ \\
\hline Hukuk ve Adalet & 63 & 33 & $\% 52,38$ \\
\hline İnsan Hakları & 29 & 15 & $\% 51,72$ \\
\hline Hayat Bilgisi & 143 & 40 & $\% 27,97$ \\
\hline Sosyal Bilgiler & 134 & 28 & $\% 20,89$ \\
\hline Görsel Sanatlar & 144 & 24 & $\% 16,66$ \\
\hline Müzik & 184 & 23 & $\% 12,50$ \\
\hline İHO Temel Dini Bilgiler & 78 & 9 & $\% 11,53$ \\
\hline Temel Dini Bilgiler (İslam 1) & 112 & 12 & $\% 10,71$ \\
\hline Şehrimiz & 120 & 12 & $\% 10,00$ \\
\hline Peygamberimizin Hayatı & 112 & 11 & $\% 9,82$ \\
\hline İnkılap Tarihi ve Atatürkçülük & 41 & 4 & $\% 9,75$ \\
\hline Temel Dini Bilgiler (İslam 2) & 105 & 9 & $\% 8,57$ \\
\hline Bilişim Teknolojileri ve Yazılım & 152 & 8 & $\% 5,26$ \\
\hline Trafik Güvenliği & 21 & 1 & $\% 4,76$ \\
\hline Teknoloji ve Tasarım & 94 & 4 & $\% 4,25$ \\
\hline Fen Bilimleri & 325 & 11 & $\% 3,38$ \\
\hline Matematik & 444 & 1 & $\% 0,22$ \\
\hline Türkçe & 524 & 0 & $\% 0,00$ \\
\hline İngilizce & 321 & 0 & $\% 0,00$ \\
\hline Toplam & 3374 & 399 & $\% 11,82$ \\
\hline
\end{tabular}

Tablo 3 incelendiğinde ilköğretim düzeyinde okutulan 20 derse ait kazanımların \%11,83'lük kısmının değer içeren kazanımlardan oluştuğu görülmektedir. Yine tablodaki verilere göre oransal olarak en fazla değer kazanımı içeren derslerin oyun ve fiziki etkinlikler, beden eğitimi, hukuk ve adalet dersleri olduğu anlaşılmaktadır. Ayrıca, Türkçe ve İngilizce programlarında değer içeren hiçbir kazanım bulunmamaktadır.

İlköğretim düzeyindeki derslerin programları değerler açısından her bir ders özelinde ayrı ayrı incelenmiş, elde edilen bulgulara ilişkin ayrıntılı açıklamalara aşağıda yer verilmiştir. 


\section{Hayat Bilgisi Dersi Öğretim Programı (İlkokul 1, 2 ve 3. Sınıflar)}

Hayat Bilgisi Dersi Öğretim Programı'nın kazanımlar ile ilgili açıklamalar kısmında toplam 3 değer ifadesi yer almaktadır. Programın tamamında ise 21 farklı değer ifadesi bulunmaktadır. Güven ve sağlığa duyarlılık değerleri programda 8 defa tekrarlanmaktadır. Aile birliğine önem verme, bireysel farklılıklara duyarl1lık, çevreye duyarlılık, dayanışma, haklara saygı, israftan kaçınma, kültürel mirasa duyarlılık, paylaşma ve yardımseverlik değerleri ise birer kez geçmektedir.

\section{Oyun ve Fiziki Etkinlikler Dersi Öğretim Programı (İlkokul 1, 2, 3 ve 4. Siniflar)}

Oyun ve Fiziki Etkinlikler Dersi Öğretim Programı'nın kazanımları ile ilgili açıklamalar kısmında toplam 71 değer ifadesi yer almaktadır. Programın kazanımlarında ise 23 farklı değer bulunmaktadır. Bu değer ifadelerinin içerisinde en fazla sorumluluk değeri $(20 \mathrm{kez})$ tekrar edilmektedir. Programda yalnızca birer kez yer alan değerler: Doğa sevgisi, doğaya duyarlılık ve sabır olarak belirtilebilir. Program bu yönüyle ilköğretim ders öğretim programları içerisinde en fazla değer barındıran derslerin başında gelmektedir.

Türkçe Dersi Öğretim Programı (İlkokul ve Ortaokul 1, 2, 3, 4, 5, 6, 7 ve 8. Siniflar)

Türkçe Dersi Öğretim Programı'nda, değerler eğitimi adıyla bir bölüm bulunmaktadır. Ancak gerek bu bölümde gerekse dersin kazanımlarında herhangi bir değer ifadesine rastlanmamıştır.

\section{Matematik Dersi Öğretim Programı (İlkokul ve Ortaokul 1, 2, 3, 4,} $5,6,7$ ve 8. Siniflar)

Matematik dersine ait öğretim programının kazanımlarının ele alındığı açıklamalar kısmında yalnızca 5. sınıf programında değer ifadesi (tutumluluk, israftan kaçınma ve çevreye duyarlılık) yer almaktadır. Diğer sınıf düzeylerinde herhangi bir değer ifadesi bulunmamaktadır. Ancak, programların değerler eğitimi başlığı altında adalet ve paylaşım, bilimsellik, esneklik, estetik, eşitlik ve tasarruf değerleri üzerinde durulmuş, bu değerler ile dersin konuları arasında nasıl ilişki kurulabileceği ve hangi durumlarda değerlerin işe yarayacağına yönelik bazı didaktik açıklamalara yer verilmiştir (Matematik Dersi Öğretim Programı, 2017, ss.9-10). Buna göre değerlerin kullanılabileceği durumlar şunlardır: 
- Adalet ve paylaşım: Problem çözme ve kurma becerilerinde.

- Bilimsellik: Bilimsel bakış açısı kazandırma, olayların incelenmesi, veri toplanması, yorumlanması gibi davranışlarda.

- Esneklik: Problem kurma ve çözme etkinliklerinde birden fazla yaklaşım dikkate almada.

- Estetik: Örüntü, geometrik şekiller ile oluşturulan yapılarda, simetri, yansıma, öteleme.

- Eşitlik: Aynı çokluğun farklı gösterimleri, anlayış, kavrayış, görüş, görünüm vb. farkl11ıkları ele almada.

- Tasarruf: Kaynakların verimli ve dikkatli bir şekilde kullanılmasında.

Görsel Sanatlar Dersi Öğretim Programı (İlkokul ve Ortaokul 1, 2, $3,4,5,6,7$ ve 8. Siniflar)

Görsel Sanatlar Dersi Öğretim Programı'nın kazanımları ile ilgili açıklamalar kısmında toplam 17 değer ifadesine yer verilmiştir. Değer ifadeleri içerisinde en çok tekrarlanan saygı $(10 \mathrm{kez})$ değeridir. Programda yalnızca birer kez yer alan değerler ise ailenin önemi, eşitlik, misafirperverlik, israf, cömertlik, yardımseverlik, özgürlük, dürüstlük ve alçakgönüllülük değerleridir.

\section{Beden Eğitimi ve Spor Dersi Öğretim Programı (İkokul ve Ortao- kul $1,2,3,4,5,6,7$ ve 8. Sinuflar)}

Beden Eğitimi Dersi Öğretim Programı'nın kazanımlar kısmında, 24 farklı değer ifadesine yer verilmiştir. Bu değer ifadelerinin içerisinde en fazla sorumluluk (32 kez) değeri geçmektedir. Programda yalnızca birer kez yer alan değerler ise doğaya duyarlılık ve doğa sevgisi değerleridir.

Müzik Dersi Öğretim Programı (İlkokul ve Ortaokul 1, 2, 3, 4, 5, 6, 7 ve 8. Siniflar)

Müzik Dersi Öğretim Programı'nın kazanımlarının ele alındığı açıklamalar kısmında toplam 3 değer ifadesi yer almaktadır. Ayrıca programın değerler eğitimi başlığı altında: arkadaşlık, çalışkanlık, duyarlılık, dürüstlük, estetik, eşitlik, iyilikseverlik, özgürlük, paylaşma, sabır, saygı, sevgi, sorumluluk, vatanseverlik ve vefa gibi değerlere yer verilmiştir. Programın tamamında ise yalnızca 
13 farklı değer yer almaktadır. Programda en çok ve 6 defa tekrarlanan değer etiktir. Programda ayrıca kültürel mirasa duyarlılık, yardımseverlik, çalışkanlık, sabır, iş birliği ve bayrak sevgisi gibi değerlere birer kez yer verilmiştir.

\section{İngilizce Dersi Öğretim Programı (İlkokul ve Ortaokul 2, 3, 4, 5, 6, 7 ve 8. Siniflar)}

İngilizce Dersi Öğretim Programı'nın kazanımlar bölümünde herhangi bir de$\breve{g}$ er ifadesi yer almamaktadır. Ancak programın değerler eğitimi başlığı altında birer defa şu değerlerden bahsedilmiştir: Çevre bilinci, tarihi miras bilinci, çalışkanlık, iş birliği, aile ve dostluk, cömertlik, yardımseverlik, merhamet, tevazu, özgüven, benlik saygısı, adalet duygusu, öz-denetim, sabır, saygı, sorumluluk, yurtseverlik ve özgürlük hissi.

\section{Fen Bilimleri Dersi Öğretim Programı (İlkokul ve Ortaokul 3, 4, 5, 6, 7 ve 8. Sinıflar)}

Bu programın açıklama kısmında “Fen Bilimleri Dersi Öğretim Programı'nda bilimsel, etik değerlere ve toplumsal değerlere vurgu yapan kazanımlara yer verilmiştir.” ifadesi yer almaktadır. Bunun yanı sıra, öğretim programının kazanımlar kısmında toplam 5 farklı değer bulunmaktadır. Sorumluluk (3 kez) en çok tekrar edilen değer, dayanışma ise en az tekrar edilen değer olarak tespit edilmiştir.

\section{İnsan Hakları, Yurttaşlık ve Demokrasi Dersi Öğretim Programı (Ilkokul 4. Sinıf)}

Programın kazanımlar kısmında toplam 12 farklı değer ifadesi yer almaktadır. $\mathrm{Bu}$ değer ifadelerinin içerisinde en fazla sorumluluk değeri (5 kez) geçmektedir. Programda yalnızca birer kez yer alan değerler: Güven, bireysel farklılıklara duyarlılık, paylaşma, sabır ve akılcılık olarak belirtilebilir. Ayrıca programın değerler eğitimi başlığı altında programda insani, millî, manevî ve evrensel değerlere yer verildiği belirtilmektedir. Bu değerler; açık fikirlilik, adalet, arkadaşlık, dostluk, eşitlik, paylaşma, sevgi, aile birliğine önem verme, duyarlılık, güven, sabır, sorumluluk, saygı ve özgürlük olarak belirtilmiştir. 
Sosyal Bilgiler Dersi Öğretim Programı (İlkokul ve Ortaokul 4, 5, 6 ve 7. Siniflar)

Sosyal Bilgiler Dersi Öğretim Programı'nın kazanımlar kısmında toplam 19 farklı değer ifadesine yer verilmiştir. Programda sorumluluk değeri 6 defa yer alarak en çok tekrar eden değer olarak öne çıkmaktadır. Bununla birlikte yardımseverlik, eşitlik, kültüre duyarlılık, etik, bağımsızlık, aile birliğine önem verme ve israftan kaçınma değerlerine birer defa yer verilmiştir.

\section{Trafik Güvenliği Dersi Öğretim Programı (İlkokul 4. Sınıf)}

Trafik Güvenliği Dersi Öğretim Programı'nın kazanımlarında yalnızca birer kez yer alan sayg1, sorumluluk ve sabır olmak üzere 3 farklı değer ifadesi yer almaktadır. Ayrıca programın değerler eğitimi başlığı altında yer alan tabloda bilimsellik, çalışkanlık, dayanışma, doğal çevreye duyarlılık, sabır, saygı, sorumluluk ve yardımseverlik olmak üzere toplam 8 değer ifadesine birer defa yer verilmiştir.

\section{Şehrimiz Dersi Öğretim Programı (Ortaokul 5, 6, 7 ve 8. Sınıflar) Ankara}

Şehrimiz Dersi Öğretim Programı'nın kazanımlarının ele alındığı açıklamalar kısmında herhangi bir değer ifadesine rastlanmamıştır. Ancak programın kazanımlarında 4 farklı değer yer almaktadır. Bu değerler; duyarlılık, bireysel farkl1lıklara duyarlılık, şefkat ve millî değerler şeklindedir. Ayrıca programın değerler eğitimi başlığı altında yer alan tabloda adalet, bilimsellik, çalışkanlık, dayanışma, duyarlılık, estetik, eşitlik, özgürlük, paylaşma, saygı, sevgi, sorumluluk, vatanseverlik ve yardımlaşma olmak üzere toplam 14 değere yer verilmiştir.

\section{İmam Hatip Ortaokulu Temel Dinî Bilgiler Dersi Öğretim Programı}

İmam Hatip Ortaokulu Temel Dinî Bilgiler Dersi Öğretim Programı'nda, değerler ile beceriler arasında ilişki kurulmuş, öğrencilere kazandırılacak sosyal becerilere yönelik etkinlikler yoluyla bazı değerlerin verilebileceği belirtilmiştir (İmam Hatip Ortaokulu Temel Dinî Bilgiler Dersi Öğretim Programı, 2017, s.25):

- Dinî ve ahlaki değerler 1şığında çevre bilincine sahip olma

- Dinî ve ahlaki değerleri benimseme 
- Millî ve dinî değer taşıyan kurumlarımızın ve eserlerimizin yaşatılmasına yönelik çalışmalara aktif olarak katılma

Belirlenen üç hedefte de değer ifadesi yer almaktadır. Ayrıca, programda yer alan ders konularının bitişiğinde bu konularda hangi değerlerin yer alması gerektiği italik biçimde gösterilmiştir:

1. Allah'a Karşı Kulluk ve Sorumluluk Şuuru: Takva

2. Allah'1 Görüyor Gibi Yaşamak: İhsan

3. Var Olma Mücadelesi: Sabır

4. Mülkün Temeli: Adalet

5. Nimetlerin Kadrini Bilmek: Şükür

6. Merhamet Etmeyene Merhamet Olunmaz: Şefkat

7. İnsanı Yücelten Değer: Tevazu

8. Kadirşinaslik: Vefa

9. Başkalarını da Düşünmek: Diğerkâmlık

Bununla birlikte, öğretim programının kazanımlarında toplam 17 farklı değer ifadesi yer almaktadır. Sorumluluk ve vefa 3 defa, adalet ve edep 2 defa, vatanseverlik, özgürlük, sabır, barış, iyilikseverlik, hayâ, adabımuaşeret kuralları, bağımsızlık, tevazu, diğerkâmlık, emanet, itidal ve toplumsal fayda değerleri ise 1 defa yer alan değerler olarak belirlenmiştir.

\section{Ortaokul Temel Dinî Bilgiler (İslam 1-2) Dersi Öğretim Programı}

Ortaokul Temel Dinî Bilgiler (İslam 1-2) dersine ait öğretim programında ayrı bir başlık halinde değerler eğitimi bölümüne yer verilmemiştir. Ancak tıpkı İmam Hatip Ortaokulu Temel Dinî Bilgiler Dersi Öğretim Programı'nda olduğu gibi sosyal beceriler başlığı altında değerlere atıf yapan fakat değerler ile ilgili herhangi bir açıklama içermeyen şu beceriler yer almaktadır (Ortaokul Temel Dinî Bilgiler (İslam 1-2) Öğretim Program1, 2017, s.10):

- Dinî ve ahlaki değerler ışı̆̆ında çevre bilincine sahip olma

- Dinî ve ahlaki değerleri benimseme

- Toplumda millî, dinî ve ahlaki değerlerin kalıcılığı için projeler üretme

Bununla birlikte, kazanımlarda toplam 4 değer ifadesine yer verildiği tespit edilmiştir. Değer ifadeleri içerisinde en çok tekrarlanan sorumluluk (4 kez) değeridir. Ayrıca, program kazanımlarında sabır (3 kez), adalet (2 kez) ve azim (1 kez) değerleri yer almaktadır. 


\section{Ortaokul ve İmam Hatip Ortaokulu Peygamberimizin Hayatı Dersi Öğretim Programı}

Ortaokul ve İmam Hatip Ortaokullarda okutulan Peygamberimizin Hayatı dersine ait öğretim programında ayrı bir başlık hâlinde değerler eğitimi bölümüne yer verilmemiştir. Ancak programın sosyal beceriler kısmında değerlere atıf yapan fakat değerler ile ilgili herhangi bir açıklama içermeyen şu beceriler yer almaktadır (Ortaokul ve İmam Hatip Ortaokulu Peygamberimizin Hayatı Öğretim Program1, 2017, s.12):

- Dinî ve ahlaki değerler 1şı̆̆ında çevre bilincine sahip olma

- Dinî ve ahlaki değerleri benimseme

Bunun yanı sıra, öğretim programının kazanımlarında toplam 10 farklı değer ifadesi yer almaktadır. Merhamet, adalet ve vefa değerleri programda 3 defa tekrarlanmıştır. Tevazu, azim, nezaket ve kanaatkârlık değerleri ise birer kez geçmektedir.

\section{Hukuk ve Adalet Dersi Öğretim Programı (Ortaokul 6, 7 veya 8. Sınıf)}

Seçmeli Hukuk ve Adalet Dersi Öğretim Programında adalet, bağımsızlık, barış, bilimsellik, cesaret, dayanışma, duyarlılık, doğruluk, dürüstlük, eşitlik, güven, merhamet, özgürlük, öz güven, sabır, saygı, sevgi, sorumluluk, tarafsızlık, vicdanlı olma ve yardımseverlik olmak üzere toplam 21 farklı değere yer verilmiştir. Programın kazanımlarında ise 5 farklı değer ifadesi bulunmaktadır. Bu değer ifadelerinin içerisinde en fazla adalet değeri (7 kez) geçmektedir. Ayrıca, barış, haklara saygı ve eşitlik değerleri yalnızca 1 kez yer alan değerler olarak tespit edilmiştir.

\section{T.C. İnkılap Tarihi ve Atatürkçülük Dersi Öğretim Programı (Orta- okul 8. Sinıf)}

T.C. İnkılap Tarihi ve Atatürkçülük Dersi Öğretim Programının giriş kısmında, dersin doğasına uygun olarak millî, manevî, insanî ve evrensel değerlere yer verilmiştir ifadesi bulunmaktadır. Bunun yanı sıra programın kazanımlar kısmında toplam 10 farklı değer ifadesi yer almaktadır. Bu değer ifadelerinin içerisinde en fazla millî birlik ve beraberlik, sorumluluk ve akılcılık değerleri (2 kez) geçmektedir. Programda ayrıca tarihsel mirasa duyarlılık, bağımsızlık, dayanışma, özgürlük, bilimsellik, çağdaşlık ve barış gibi değerlere birer kez yer verilmektedir. 
Teknoloji ve Tasarım Dersi Öğretim Programı (Ortaokul 7 ve 8. Sınıflar)

Teknoloji ve Tasarım Dersi Öğretim Programı'nın kazanımlar ile ilgili açıklamalar kısmında, toplam 3 değer ifadesi bulunmaktadır. Programın kazanımlarında ise 9 adet farklı değer yer almaktadır. Programda duyarlılık değeri üç 3 defa geçmektedir. Programda ayrıca yardımseverlik, iyilikseverlik, etik, çevreye duyarlılık ve estetik değerlerine de birer defa yer verilmiştir.

\section{İlköğretim Programlarında Yer Alan Değerler, Tekrarlanma Sıklık- ları ve İlişkili Oldukları Değer Kategorileri}

Araştırma kapsamında ilköğretim düzeyinde yer alan 20 dersin öğretim programlarına ait kazanımlar ayrıntılı bir şekilde incelenmiştir. Bu inceleme sonucunda program kazanımlarında tespit edilen değerler, bu değerlerin tekrarlanma sıklıkları ve ilişkili oldukları değer kategorileri aşağıda gösterilmiştir:

\begin{tabular}{|c|c|c|c|c|c|c|c|}
\hline $\begin{array}{l}\text { Değer } \\
\text { Kategori- } \\
\text { leri }\end{array}$ & Değerler & $\begin{array}{l}\text { Tekrarlanma } \\
\text { Sayısı }\end{array}$ & Toplam & $\begin{array}{l}\text { Değer } \\
\text { Kategori- } \\
\text { leri }\end{array}$ & Değerler & $\begin{array}{l}\text { Tekrarlan- } \\
\text { ma Sayısı }\end{array}$ & $\begin{array}{l}\text { Top- } \\
\text { lam }\end{array}$ \\
\hline \multirow{16}{*}{ 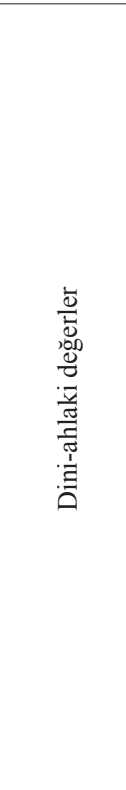 } & Etik & 14 & \multirow{16}{*}{67} & \multirow{13}{*}{ 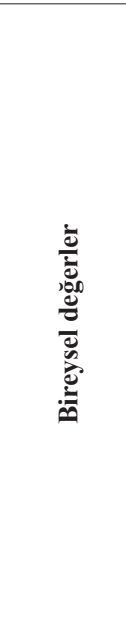 } & Sayg1 & 38 & \multirow{13}{*}{154} \\
\hline & Vefa & 11 & & & $\begin{array}{l}\text { Sağlığa } \\
\text { duyarlılık }\end{array}$ & 37 & \\
\hline & Sabir & 10 & & & Çalışkanlık & 25 & \\
\hline & Merhamet & 7 & & & Dürüstlük & 16 & \\
\hline & Sevgi & 5 & & & Güven & 16 & \\
\hline & Şefkat & 4 & & & $\begin{array}{l}\text { Farklilıklara } \\
\text { duyarlılık }\end{array}$ & 8 & \\
\hline & $\begin{array}{l}\text { Manevî de- } \\
\text { ğerler }\end{array}$ & 3 & & & Öz sayg1 & 6 & \\
\hline & İyilikseverlik & 3 & & & Cesaret & 2 & \\
\hline & Edep & 2 & & & Azim & 2 & \\
\hline & Tevazu & 2 & & & Öz kontrol & 1 & \\
\hline & Vicdanlı olmak & 1 & & & Farkındalık & 1 & \\
\hline & Hayâ & 1 & & & İtidal & 1 & \\
\hline & Diğerkâmlık & 1 & & & $\begin{array}{l}\text { Çok yön- } \\
\text { lülük }\end{array}$ & 1 & \\
\hline & Emanet & 1 & & \multirow{3}{*}{ 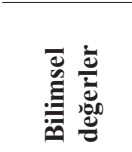 } & Bilimsellik & 4 & \multirow{3}{*}{8} \\
\hline & $\begin{array}{l}\text { Alçak gönül- } \\
\text { lülük }\end{array}$ & 1 & & & Akılcılık & 3 & \\
\hline & Kanaatkârlık & 1 & & & Gerçekçilik & 1 & \\
\hline
\end{tabular}




\begin{tabular}{|c|c|c|c|c|c|c|c|}
\hline \multirow{14}{*}{ 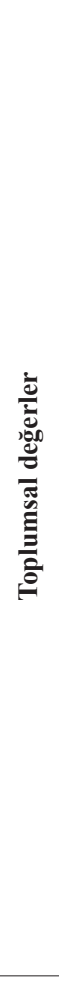 } & Sorumluluk & 92 & \multirow{14}{*}{200} & \multirow{9}{*}{ 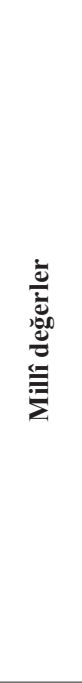 } & $\begin{array}{l}\text { Kültürel } \\
\text { mirasa } \\
\text { duyarll11k }\end{array}$ & 25 & \multirow{9}{*}{77} \\
\hline & Adalet & 26 & & & $\begin{array}{l}\text { Vatanse- } \\
\text { verlik }\end{array}$ & 15 & \\
\hline & Arkadaşlık & 14 & & & $\begin{array}{l}\text { Tarihsel } \\
\text { mirasa } \\
\text { duyarlılık }\end{array}$ & 12 & \\
\hline & Yardimseverlik & 13 & & & $\begin{array}{l}\text { Kültüre } \\
\text { duyarlılık }\end{array}$ & 8 & \\
\hline & Duyarlılık & 12 & & & $\begin{array}{l}\text { Millî birlik } \\
\text { ve beraberlik }\end{array}$ & 7 & \\
\hline & İşbirliği & 8 & & & $\begin{array}{l}\text { Millî de- } \\
\text { ğerler }\end{array}$ & 5 & \\
\hline & Paylaşma & 7 & & & Bağımsızlık & 3 & \\
\hline & Dostluk & 7 & & & $\begin{array}{l}\text { Millet } \\
\text { sevgisi }\end{array}$ & 1 & \\
\hline & Dayanışma & 6 & & & $\begin{array}{l}\text { Bayrak } \\
\text { sevgisi }\end{array}$ & 1 & \\
\hline & Barış & 5 & & \multirow{5}{*}{ 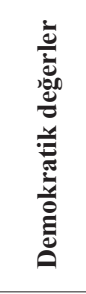 } & Özoürlük & 18 & \multirow{5}{*}{38} \\
\hline & Nezaket & 4 & & & Ozguriuk & 18 & \\
\hline & $\begin{array}{l}\text { Adab-1 mua- } \\
\text { şeret }\end{array}$ & 3 & & & Eşitlik & 13 & \\
\hline & Aile bağları & 2 & & & $\begin{array}{l}\text { Haklara } \\
\text { sayg1 }\end{array}$ & 6 & \\
\hline & $\begin{array}{l}\text { Toplumsal } \\
\text { fayda }\end{array}$ & 1 & & & Çağdaşlık & 1 & \\
\hline \multirow{4}{*}{ 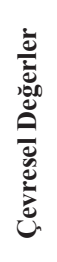 } & Doğa sevgisi & 3 & \multirow{4}{*}{23} & \multirow{2}{*}{ 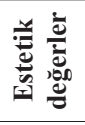 } & & & \multirow[b]{2}{*}{14} \\
\hline & $\begin{array}{l}\text { Çevreye } \\
\text { duyarlılık }\end{array}$ & 18 & & & Estetik & 14 & \\
\hline & \multirow{2}{*}{$\begin{array}{l}\text { Doğaya duyar- } \\
\text { l1lık }\end{array}$} & \multirow[t]{2}{*}{2} & & 兰 & $\begin{array}{l}\text { İsraftan } \\
\text { kaçınma }\end{array}$ & 5 & \multirow{2}{*}{8} \\
\hline & & & & 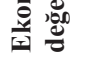 & Tutumluluk & 3 & \\
\hline
\end{tabular}

Şekil 2. İlköğretim düzeyindeki öğretim programlarında yer alan değerler, tekrarlanma sıklıkları ve değer kategorileri

İlköğretim düzeyindeki 20 dersin öğretim programında yer alan değerler ve tekrarlanma sıklığını gösteren Şekil 2 incelendiğinde, programların tamamında toplam 65 farklı değere yer verildiği görülmektedir. Yine tablodaki veriler, ilköğretim programlarında en fazla önemsenen değerin sorumluluk olduğunu ve tüm programlarda toplam 92 defa tekrarlandığını göstermektedir. Sorumluluk dışında en fazla tekrarlanan on değer sirasiyla saygı (38), sağlı̆̆a duyarlılık (37), adalet (26), kültürel mirasa duyarlılık (25), çalışkanlık (25), çevreye duyarlllı (18), özgürlük (18), dürüstlük (16), güven (16) ve vatanseverlik (15) değerleridir. İlköğretim programlarında yer alan 65 farklı değerin, hitap ettiği kitle ve özellikleri dikkate alındığında; dinî-ahlaki, bireysel, toplumsal, millî, 
demokratik, bilimsel, ekonomik, çevresel ve estetik olmak üzere 9 farklı değer kategorisi altında toplanabileceği söylenebilir. Yine tablodaki verilere göre en fazla önem verilen değerin toplumsal değerler olduğu ve bu kategori altında yer alan farklı değerlerin 200 defa tekrarlandığı görülmektedir. Bunu 154 defa tekrarlanan bireysel değerler izlemektedir. İlköğretim programlarında en az tekrarlanan değer kategorisi ise estetik (14), ekonomik (8) ve bilimsel (kuramsal) (8) değer kategorileri olmuştur. Değerler kategorisi ve tekrarlanma sıklıkları dikkate alındığında en fazla önem verilen değerlerin toplumsal ve bireysel değerler olduğu, buna karşın ilköğretim programlarında çevresel, bilimsel ve ekonomik değerlerin en az önemsenen değerler olduğu ileri sürülebilir.

\section{Illköğretim Programlarında Yer Alan Değerlerin Derslere Göre Yaygınlığı}

İlköğretim programlarının kazanımlarında tespit edilen değerlerin dersler açısından yaygınlığına ilişkin tablo aşağıda verilmiştir.

\begin{tabular}{lc}
\hline \multicolumn{2}{l}{ Tablo 4: İlköğretim Programlarında Yaygın Olan Değerlerin Derslere Göre Dağılımı } \\
\hline Değerler & Tüm Dersler İçerisindeki Yaygınlığı \\
\hline Sorumluluk & $14 / 20$ \\
Sayg1 & $09 / 20$ \\
Çevreye duyarlılık & $08 / 20$ \\
Adalet & $07 / 20$ \\
Sabır & $07 / 20$ \\
Özgürlük & $07 / 20$ \\
Külttürel mirasa duyarlılık & $06 / 20$ \\
Dürüstlük & $06 / 20$ \\
Vatanseverlik & $06 / 20$ \\
Yardımseverlik & $06 / 20$ \\
\hline
\end{tabular}

İlköğretim programlarındaki değer içeren kazanımların farklı programlarda yer alma durumunu gösteren tablo incelendiğinde, sorumluluk, saygı, çevreye duyarlılık, adalet, sabır, özgürlük, kültürel mirasa duyarlılık, dürüstlük, vatanseverlik ve yardımseverlik değerlerinin 20 ders içerisinde 6 ve daha fazla derste tekrarlandığı görülmektedir. Bu değerler içerisinde sorumluluk, saygı ve çevreye duyarlılık değerlerinin farklı derslerde geçen en yaygın değerler olduğu anlaşılmaktadır. 


\section{İlköğretim Programlarında Sık Tekrarlanan Değerler ile Kök De- ğerlerin Karşılaştırılması}

Tüm programların açıklama kısmında bulunan ve Millî Eğitim Bakanlığı tarafından kazandırılması istenen kök değerler ile programların kazanımlarında yer alan ve en sık tekrarlanan değerler mukayese edildiğinde farklı bir tablo ortaya çıkmaktadır. Aşağıda Bakanlığın benimsediği kök değerler ile 2017 İlköğretim Programlarının kazanımlarında yer alan ve en sık tekrarlanan değerlerin kıyaslandığı bir tablo verilmiştir.

\begin{tabular}{ll}
\hline Tablo 5: Kök Değerler ile 2017 & Programında En Sık Tekrarlanan Değerlerin Karşıılaştırılması \\
\hline Kök Değerler & 2017 Programlarında En Sık Tekrarlanan Değerler \\
\hline Sorumluluk & Sorumluluk (92) \\
Saygı & Saygı (38) \\
& Sağlığa Duyarlılık (37) \\
Adalet & Adalet (26) \\
& Çalı̧̧kanlık (25) \\
& Kültürel Mirasa Duyarlılık (25) \\
& Özgürlük (18) \\
& Çevreye Duyarlılık (18) \\
Dürüstlük & Dürüstlük (16) \\
& Güven (16) \\
Dostluk & Dostluk (7) \\
Öz denetim & Öz kontrol (1) \\
Sabır & Sabır (10) \\
Sevgi & Sevgi (5) \\
Vatanseverlik & Vatanseverlik (15) \\
Yardımseverlik & Yardımseverlik (13) \\
\hline
\end{tabular}

Tablo 5 incelendiğinde, Bakanlığın önemsediği kök değerlerin ilköğretim programlarındaki kazanımlar ile belirli ölçüde uyum gösterdiği görülmektedir. Ancak kök değerlerde yer alan öz kontrol (1), sevgi (5) ve dostluk (7) gibi değerler ilköğretim programlarının kazanımlarında sınırlı sayıda yer almaktadır. Buna karşılık kök değerlerde olmayan sağlığa duyarlılık (37), çalışkanlık (25) ve kültürel mirasa duyarlılık (25) gibi değerlerin kazanımlarda sıkça tekrarlandığı anlaşılmaktadır.

\section{Sonuç ve Tartışma}

Bu çalışmada, 2017 yılında yenilenen ilköğretim ders programları değerler açısından incelenmiştir. Elde edilen bulgulara göre 2017 programlarında önceki programlara kıyasla değerlere ve değerler eğitimine özel vurgu yapılmış, ders 
programlarının giriş kısmında değerler konusu ayrı bir başlık altında işlenmiştir. Programlarda duyuşsal alana hitap eden ve değer içeren çok sayıda kazanım yer almaktadır. Programlarda eğitim kurumlarının değer eğitimini amaç edinmesi gerektiği, eğitimin değerlerle şekillenmiş bir etkinlik olarak görülmesi gerektiği belirtilmiştir (Türkçe Dersi Öğretim Programı, 2017, s.7). Yaşaroğlu (2018) tarafından eski öğretim programlarına yönelik olarak yapılan araştırmada, 1968 ve 1998 programlarında değerler eğitimine ayrı bir başlıkta yer verilmediği belirtilmektedir. Aynı araştırmada, 2005 programında Programın Temel Yapısı ve Başlığı altında değer ifadelerinin yer aldığı, 2017 ve 2018 programlarında ise değerlere özel vurgu yapıldığı ifade edilmiştir. Söz konusu bulgular bu çalışmanın bulgularıyla uyum göstermektedir.

2017 ilköğretim programlarının değer felsefesi iyi insan iyi vatandaş anlayışı üzerine temellendirilmiştir. Yenilenen ilköğretim programlarında, bireyin çok yönlü gelişimine özel vurgu yapılmış, değerlerin birey gelişimindeki önemi üzerinde durulmuştur. Yaşaroğlu, (2018) 2005 yılı ve sonrasında geliştirilen programların giriş kısımlarında değer vurgusunun gittikçe arttığını belirtmektedir. Söz konusu araştırmanın sonuçları elde ettiğimiz bulgular ile örtüşmektedir. 2017 programı, değerlerin işlevi üzerinde durmakta, programda kazandırılacak değerlerin, bireyin sağlıklı ve dengeli biçimde gelişmesine katkı sağlayacağı ifade edilmektedir. Ayrıca değerlerin yeni nesillere aktarılmasının kültürel devamlılığın sağlanması ve eğitim hedeflerine ulaşılması açısından önemli olduğuna işaret edilmektedir (Bilişim Teknolojileri ve Yazılım Dersi Öğretim Program1, 2017, s.8).

Yenilenen ilköğretim programlarında insan ilişkilerinin değerler tarafından düzenlendiğine vurgu yapılarak, millî, manevî ve evrensel değerlerin öğrencilere tanıtılması, benimsetilmesi ve bunların içselleştirilerek davranışa dönüştürülmesinde ailenin, toplumun ve medyanın yanı sıra öğretim programlarının da önemli rolünün olduğu belirtilmektedir (Oyun ve Fiziki Etkinlikler Dersi Öğretim Programı, 2017, s.8). Programda ayrıca öğretim programının uygulayıcısı olan öğretmenin değerler eğitimine ilişkin farkındalığının yanı sıra yeterliliğinin, becerisinin ve model olabilme özelliğinin de önemli olduğu vurgulanmıştır.

2017 ilköğretim programlarının organizasyon yapısına bakıldığında, değerlerin programın ana omurgası içerisinde yer aldığı görülmektedir. Öğretim programlarında, değerlere yaşam becerileri ve kavramlar gibi eğitimin temel öncelikleri arasında yer verilmiştir (TTKB, 2017, s.7). Programların organizasyonu içerisinde değerlerin ayrı bir bölüm olarak yer alması, konuya verilen önemin 
göstergesi olarak görülebilir. Baş (2017) ve Yaşaroğlu (2018) tarafından yapılan çalışmalarda da son yıllarda yenilenen programlarda değerlere daha fazla önem verildiği belirtilmiştir.

İlköğretim programlarında ayrıca değer öğretiminde nasıl bir yol izleneceğine yönelik açıklamalara yer verilmiştir. Bu durum eski programlara kıyasla ileri bir adım olarak değerlendirilebilir. Nitekim benzer bir tespit Kardaş ve Cemal (2017) tarafından yapılmış, eski programlarda değer eğitiminde hangi değerlerin olması gerektiği ve değer aktarımının nasıl sağlanacağına ilişkin belirsizliğe işaret edilmiştir.

2017 programlarında, daha önceki programlardan farklı olarak, kök değerlerden bahsedilmiştir. Adalet, dostluk, dürüstlük, öz denetim, sabır, saygı, sevgi, sorumluluk, vatanseverlik, yardımseverlik değerleri programlarda kök değerler olarak belirtilmiştir (Hayat Bilgisi Dersi Öğretim Programı, 2017, s.8). Kök değerlerle birlikte bu değerlere ilişkin davranış örneklerine de yer verilmiştir. Kök değerler ve bunlara ilişkin gösterge davranışlar, öğrencilerin kişisel ve sosyal yaşamlarında ve insan ilişkilerinde nasıl bir tutuma sahip olmaları gerektiğine yöneliktir. Programda yer alan kök değerler, sosyal (adalet, dostluk, dürüstlük, saygı, yardımseverlik), kişisel (öz denetim, sabır, sorumluluk, sevgi) ve millî (vatanseverlik) değer kategorilerine yöneliktir. Keskin (2012) tarafından yap1lan bir çalışmada, ilköğretim programlarında genellikle "sevgi, saygı, adil olma, barış, hoşgörü, yardımseverlik, vatanseverlik ve dürüstlük” gibi değerlerin ortak değerler olarak yer aldığı belirtilmektedir.

Yenilenen ilköğretim programlarında yer alan her dersin programında farklı değerlere yer verilmiştir. Örneğin Matematik dersi öğretim programında, adalet, paylaşım, bilimsellik, esneklik, eşitlik ve tasarruf gibi daha çok bilimsel değerlere yer verilirken (Matematik Dersi Öğretim Program1, 2017, ss.9-10), İmam Hatip Ortaokulu Temel Dini Bilgiler dersi öğretim programında takva, ihsan, sabır, adalet, şükür, şefkat, tevazu, vefa ve diğerkâmlık gibi dinî değerlere yer verilmiştir (İmam Hatip Ortaokulu Temel Dini Bilgiler Dersi Öğretim Program1, 2017, s.25).

İlköğretim düzeyindeki program kazanımlarının \%11,83'lük kısmı, değer içeren kazanımlardan oluşmaktadır. Dersler açısından bakıldığında, en fazla değer içeren kazanım oyun ve fiziki etkinlikler, beden eğitimi ve hukuk ve adalet derslerinde yer almaktadır. Değer çeşitliliği açısından bakıldığında ise en fazla farklı değer ifadesi bulunan ders beden eğitimi dersidir. İlköğretim düzeyindeki 20 dersin öğretim programlarının tamamında toplam 65 farklı değer bulunmak- 
tadır. Bu değerler içerisinde sorumluluk, saygı ve çevreye duyarlılık değerleri farklı derslerde geçen en yaygın değerlerdir. Tüm programlarda en fazla önemsenen değer, 92 defa tekrarlanan sorumluluk değeridir. Sorumluluk dişında en fazla tekrarlanan on değer sirasıyla sayg1, sağlığa duyarlılık, adalet, kültürel mirasa duyarlılık, çalışkanlık, çevreye duyarlılık, özgürlük, dürüstlük, güven ve vatanseverlik değerleridir. İlköğretim programlarında sık tekrarlanan değerler ile kök değerler kıyaslandığında, belirli ölçüde örtüştüğü görülmektedir. Kardaş ve Cemal (2017) tarafından 2017 öncesi Türkçe öğretiminde öne çıkan değerleri tespit etmek amacıyla yapılan bir çalışmada en sık tekrarlanan 10 değerin sayg1, sevgi, yardımseverlik, dürüstlük, çalışkanlık, sorumluluk, hoşgörü, bilimsellik, aile birliğine önem verme, duyarlılık olduğu rapor edilmiştir. $\mathrm{Bu}$ değerlerin 2017 ilköğretim programlarında en sık tekrarlanan değerlerle büyük ölçüde örtüştügü görülmektedir. Ancak 2017 Türkçe öğretim programının değer ifade eden kazanım olmaması dikkat çekicidir. Ayrıca Kuş, Merey ve Karatekin (2013) ilköğretim dördüncü ve beşinci sınıf sosyal bilgiler ders kitaplarında en s1k vurgulanan değerlerin duyarlılık, vatanseverlik, sorumluluk, sevgi ve dayanışma olduğunu belirtirken, temizlik, dürüstlük ve hoşgörü değerlerine en az yer verildiğini belirtmiş̧lerdir. Bu çalışmada elde edilen sonuçlar sık tekrarlanan değerler açısından büyük benzerlik göstermektedir. Aktan ve Kılıç (2015) tarafından yapılan çalışmada da sosyal bilgiler öğretim programında sevgi, yardımseverlik, sayg1, estetik ve özgürlük değerlerinin en fazla tekrarlanan değerler olduğu belirtilmiştir. Aktan ve Padem (2013) tarafından yapılan başka bir araştırmada, ilköğretim sosyal bilgiler ders kitabındaki okuma metinlerinde sorumluluk, sevgi, yardımseverlik ve dayanışma değerlerinin en fazla tekrarlandığı; sağlıklı olmaya önem verme, temizlik ve vatanseverlik değerlerinin ise az tekrarlanan değerler olduğu belirtilmiştir. Güzel Candan ve Ergen (2014), ilköğretim üçüncü sınıf hayat bilgisi ders kitaplarında en çok yer verilen değerlerin sevgi ve sorumluluk olduğunu ifade etmişlerdir. Şahin ve Başgül (2019) tarafından yapılan çalışmada ise matematik ders kitaplarında en fazla sorumluluk değerine, en az saygı değerine yer verildiği tespit edilmiştir. Alanyazındaki bu sonuçlar, özellikle sorumluluk değeri bakımından elde edilen sonuçları desteklemektedir. Ancak, 2017 öncesine ait programlar ve ders kitaplarında s1nırlı düzeyde yer alan sağlığa duyarlılık, saygı ve vatanseverlik değerleri 2017 programlarında en çok tekrar edilen on değer arasında yer almaktadır. Bir başka çalışmada ortaokul Türkçe ders kitaplarında en çok kullanılan değerlerin; estetik, sevgi, nezaket, çalışkanlık; en az kullanılan değerlerin ise barış, sadelik, alçakgönüllülük ve hoşgörü olduğu, ders kitabındaki temalar ile kazanımlarda yer alan değerlerin örtüşmediği tespit edilmiştir (Baki, 2019). 
2017 ilköğretim programlarında yer alan 65 farklı değer, ifade ettiği anlam bakımından dinî-ahlaki, bireysel, toplumsal, millî, demokratik, bilimsel, ekonomik, çevresel ve estetik olmak üzere 9 farklı değer kategorisi altında toplanmaktadır. Bu sınıflama alanyazındaki benzer sınıflamalara büyük ölçüde uymaktadır. Ancak, Spranger (2001), Allport, Vernon ve Lindzey (1970) ile Güngör'ün (2000) "politik” olarak ifade ettikleri değer kategorisinde yer alan özgürlük, eşitlik ve haklara saygı değerleri demokratik değerler kategorisi altında verilmiştir.

2017 ilköğretim programlarında değer kategorileri ve tekrarlanma sıklıkları dikkate alındığında en fazla önem verilen değerlerin toplumsal ve bireysel değerler olduğu, buna karşın çevresel, bilimsel ve ekonomik değerlerin az önemsenen değerler olduğu görülmektedir. İdi Tulumcu ve Tulumcu (2015) tarafindan yapılan araştırmada, 1924 ile 2013 arası ilköğretim ikinci kademe Türkçe dersi programlarında dinî ve iktisadî değerlere diğer değerlere oranla daha az yer verildiği belirtilmiştir. Ayrıca Sosyal Bilgiler Öğretim Programı'nda yer alan değerleri inceleyen Aktan ve Kılıç (2015), bilimsellik değerlerini programlarda en az yer alan değerler olduğunu ifade etmiştir. Değer kategorilerine ilişkin alanyazındaki bulgular, bu çalışmada elde edilen sonuçları destekler niteliktedir.

Sonuç olarak, 2017 yılında yenilenen ilköğretim programlarının bireyleri çok yönlü yetiştirmeyi hedeflediği ve bu amaçla farklı değer kategorilerinde tutum ve davranış kazandırmayı önemsediği görülmektedir. Programların değer içeren tüm kazanımları birlikte değerlendirildiğinde, öğrencilerin çok yönlü gelişimi ve dengeli bir insan olarak yetiştirilmelerinin hedeflendiği anlaşılmaktadır. Esasen dengeli insan arayışı programların açıklama kısmında ifade edilmekte ve öğrencilerin çok yönlü gelişimine özel vurgu yapılmaktadır. Ayrıca 2023 Eğitim Vizyon Belgesi'nin temel felsefesinde insanın çok yönlülüğüne değinilmiş, eğitim sistemlerinin, ancak insan doğasına ait tüm unsurlara ilişkin bütüncül bir sorumluluk geliştirebildiği ölçüde başarılı olabileceği belirtilmiştir (MEB, 2018).

\section{Kaynakça}

Aktan, O. ve Kilıç, A. (2015). Sosyal bilgiler öğretim programındaki değerleri 100 temel eserde bulunan değerlerin destekleme durumu. Değerler Ĕ̈itimi Dergisi, 12(30), 7-68.

Aktan, O. ve Padem, S. (2013). İlköğretim 5. sınıf sosyal bilgiler ders kitabında kullanılan okuma metinlerinde yer alan değerler. E-AJI (Asian Journal of Instruction), 1(2), 44-55 
Allport, G. W., Vernon, P. ve G. Lindzey. (1970). Study of values (Revised $3^{\text {th }}$ ed). Chicago: The Riverside Publishing Company.

Baki, Y. (2019). Ortaokul Türkçe ders kitaplarındaki metinlerin değer aktarımı açısından incelenmesi. Değerler Eğitimi Dergisi, 17(37), 109-146.

Baş, M. (2017). 2009 ve 2015 İlkokul matematik dersi öğretim programları ile 2017 ilkokul matematik dersi öğretim programı karşılaştırması. Yüzüncü Yll Üniversitesi Eğitim Fakültesi Dergisi, 14(1), 1219-1258.

Çekin, A. (2012). Değer açısından ilköğretim din kültürü ve ahlak bilgisi dersi kazanımları: Bir içerik analizi. Dinbilimleri Akademik Araştırma Dergisi, 12(2), 105-119.

Çelik, F. (2010). 5. sınıf Sosyal Bilgiler programında sorumluluk, estetik ve doğal çevreye duyarlılık değerlerinin kazandırılmasına ilişkin öğrenci ve öğretmen görüşleri. (Yayımlanmamış Yüksek Lisans Tezi). Eskişehir: Anadolu Üniversitesi.

Davey, L. (2009). The application of case study evaluations. (Çev: T. Gökçek). Elementary Education Online, 8(2), 1-3.

Demir, K. ve Demirhan İşcan, C. (2007). Hayat bilgisi dersinde değerler ve değerler eğitimi. 1. Ulusal İlköğretim Kongresi. 15-17 Kasım 2007, Hacettepe Üniversitesi, Ankara.

Gall, D.M., Gall, P.J., ve Borg, W.R. (2007). Educational research: An introduction. Boston, MA: Pearson

Gömleksiz, M. N. ve Cüro, E. (2011). Sosyal bilgiler dersi öğretim programında yer alan değerlere ilişkin öğrenci tutumlarının değerlendirilmesi. Uluslararası Insan Bilimleri Dergisi, 8(1), 95-134.

Güngör, E. (2000). Değerler psikolojisi üzerine araştırmalar (3. Bask1). İstanbul: Ötüken Yayınları.

Güzel Candan, D. ve Ergen, G. (2014). 3. Sınıf hayat bilgisi ders kitaplarının temel evrensel değerleri içermesi bakımından incelenmesi. Uşak Üniversitesi Sosyal Bilimler Dergisi, 7(1), 134-161.

İdi Tulumcu, F. İ.ve Tulumcu, F. M. (2015). İlköğretim ikinci kademe Türkçe dersi programlarında yer alan değerler. Değerler Ĕgitimi Dergisi, 13(29), 535-560.

Karasar, N. (2009). Bilimsel araştırma yöntemi (19. Bask1). Ankara: Nobel Yayıncilik.

Kardaş, M. ve Cemal, S. (2017). Değerler eğitimi ve Türkçe öğretiminde değer eğitimi üzerine yapılan araştırmalara ilişkin kaynakça denemesi. Karadeniz Sosyal Bilimler Dergisi, 9(16), 383-412. 
Kaymakcan, R. ve Meydan, H. (2011). Din kültürü ve ahlak bilgisi programları ve öğretmenlerine göre değerler eğitimi. Değerler Eğitimi Dergisi, 9(21), 29-55.

Keskin, Y. (2012). İlköğretim programlarındaki bazı ortak değerlerin kazanılma düzeylerinin bazı değişkenler açısından karşılaştıılması (Samsun ili örneği). The Journal of Academic Social Science Studies, 5(8), 827-849. https://doi.org/10.9761/jasss_352

Kuş, Z., Merey, Z. ve Karatekin, K. (2013). İlköğretim 4. ve 5. sınıf sosyal bilgiler ders kitaplarında yer alan değerler. Değerler Ĕgitimi Dergisi, 11(25), 183-214.

Kuzu, K. (2015). Okul öncesi öğretmenlerinin değerler eğitimi hakkındaki görüşleri ve bu görüşlerin sınıf içi uygulamalara yansıması (Yayımlanmamış yüksek lisans tezi). Uludağ Üniversitesi, Eğitim Bilimleri Enstitüsü, Bursa.

McMillan, J. H. (2012). Educational research: Fundamentals for the consumer. Boston: Pearson.

MEB. (2017a). Beden eğitimi ve spor dersi öğretim programı (ortaokul 5, 6, 7 ve 8. siniflar). http://mufredat.meb.gov.tr/Programlar.aspx adresinden 25.12.2017 tarihinde alınd1.

MEB. (2017b). Bilişsim teknolojileri ve yazılım dersi ögretim programı (ortaokul 5 ve 6. siniflar). http://mufredat.meb.gov.tr/Programlar.aspx adresinden 25.12.2017 tarihinde alındı.

MEB. (2017c). Fen Bilimleri dersi ögretim programı (ilkokul ve ortaokul 3, 4, 5, 6, 7 ve 8. siniflar). http://mufredat.meb.gov.tr/Programlar.aspx adresinden 25.12.2017 tarihinde alınd.

MEB. (2017d). Görsel sanatlar dersi ögretim programı (ilkokul ve ortaokul 1, 2, 3, 4, 5, 6, 7 ve 8. siniflar). http://mufredat.meb.gov.tr/Programlar.aspx adresinden 25.12.2017 tarihinde alınd1.

MEB. (2017e). Hayat bilgisi dersi öğretim programı (ilkokul 1, 2 ve 3. sinıflar). http://mufredat.meb.gov.tr/Programlar.aspx adresinden 25.12.2017 tarihinde alındi.

MEB. (2017f). Hukuk ve adalet dersi ögretim programı (ortaokul 6, 7 veya 8. sinif). http://mufredat.meb.gov.tr/Programlar.aspx adresinden 25.12.2017 tarihinde alındı.

MEB. (2017g). Imam hatip ortaokulu temel dini bilgiler dersi ögretim programı. http://mufredat.meb.gov.tr/Programlar.aspx adresinden 25.12.2017 tarihinde alındi. 
MEB. (2017h). İngilizce dersi ögretim programı (ilkokul ve ortaokul 2, 3, 4, 5, 6, 7 ve 8. siniflar). http://mufredat.meb.gov.tr/Programlar.aspx adresinden 25.12.2017 tarihinde alınd1.

MEB. (2017i). Insan hakları, yurttaşlık ve demokrasi dersi öğretim programı (ilkokul 4. sinif). http://mufredat.meb.gov.tr/Programlar.aspx adresinden 25.12.2017 tarihinde alınd1.

MEB. (2017j). Matematik dersi öğretim programı (ilkokul ve ortaokul 1, 2, 3, 4, 5, 6, 7 ve 8. sinıflar). http://mufredat.meb.gov.tr/Programlar.aspx adresinden 25.12.2017 tarihinde alınd.

MEB. (2017k). Müzik dersi ögrretim programı (ilkokul ve ortaokul 1, 2, 3, 4, 5 , 6, 7 ve 8. siniflar). http://mufredat.meb.gov.tr/Programlar.aspx adresinden 25.12.2017 tarihinde alınd1.

MEB. (20171). Ortaokul temel dini bilgiler (İslam 1-2) dersi öğretim programı. http:// mufredat.meb.gov.tr/Programlar.aspx adresinden 25.12.2017 tarihinde alındı.

MEB. (2017m). Ortaokul ve imam hatip ortaokulu peygamberimizin hayatı dersi öğretim programi. http://mufredat.meb.gov.tr/Programlar.aspx adresinden 25.12.2017 tarihinde alınd1.

MEB. (2017n). Oyun ve fiziki etkinlikler dersi öğretim programı (ilkokul 1, 2, 3 ve 4. siniflar). http://mufredat.meb.gov.tr/Programlar.aspx adresinden 25.12.2017 tarihinde alınd1.

MEB. (2017o). Sosyal bilgiler dersi öğretim programı (ilkokul ve ortaokul 4, 5, 6 ve 7. siniflar). http://mufredat.meb.gov.tr/Programlar.aspx adresinden 25.12.2017 tarihinde alınd1.

MEB. (2017p). Şehrimiz ... dersi öğretim programı (ortaokul 5, 6, 7 ve 8. sinıflar). http://mufredat.meb.gov.tr/Programlar.aspx adresinden 25.12.2017 tarihinde alınd.

MEB. (2017r). T.C. inkılap tarihi ve Atatürkçülük dersi öğretim programı (ortaokul 8. sinif). http://mufredat.meb.gov.tr/Programlar.aspx adresinden 25.12.2017 tarihinde alınd1.

MEB. (2017s). Teknoloji ve tasarım dersi öğretim programı (ortaokul 7 ve 8. siniflar). http://mufredat.meb.gov.tr/Programlar.aspx adresinden 25.12.2017 tarihinde alındı.

MEB. (2017t). Trafik güvenliği dersi ögretim programı (ilkokul 4. sinıf). http://mufredat.meb.gov.tr/Programlar.aspx adresinden 25.12.2017 tarihinde alınd.

MEB. (2017u). Türkçe dersi öğretim programı (ilkokul ve ortaokul 1, 2, 3, 4, 5, 6, 7 ve 8. siniflar). http://mufredat.meb.gov.tr/Programlar.aspx adresinden 25.12.2017 tarihinde alınd. 
MEB. (2018). Güçlü yarınlar için 2023 eğitim vizyonu. http://2023vizyonu. meb.gov.tr/doc/2023_EGITIM_VIZYONU.pdf adresinden 15.01.2020 tarihinde alınd.

Merriam, S. B. (2018). Nitel araştırma: Desen ve uygulama için bir rehber (3. Baskıdan Çeviri, Çeviri Editörü: S. Turan). Ankara: Nobel Yayın Dağıtım.

Miles, M. B. ve Huberman, A. B. (1994). Qualitative data analysis (2nd Ed.). Thousand Oaks, CA: Sage Publications, Inc.

Öğretim programı taslaklarında değerler eğitimi. (2017, Kasım 8). Tedmem: https://tedmem.org/mem-notlari/gorus/ogretim-programi-taslaklarinda-degerler-egitimi adresinden alınd1.

Spranger, E. (2001). İnsan tipleri bir kişilik psikolojisi. İstanbul: İz Yayınları.

Şahin, Ö. ve Başgül, M. (2019). Ortaokul matematik ders kitaplarında sosyal değerler. Dicle University Journal of Ziya Gokalp Education Faculty, 34, 90-104.

Talim ve Terbiye Kurulu Başkanlığı (TTKB). (2017, Temmuz 18). Müfredatta yenileme ve değişiklik çalışmalarımı üzerine... https://ttkb.meb.gov.tr/ meb_iys_dosyalar/2017_07/18160003_basin_aciklamasi-program.pdf adresinden 25.12.2019 tarihinde alındı.

Yaşaroğlu, C. (2018). Öğretim programlarında değerler: Hayat bilgisi dersi örneği. Anemon Muş Alparslan Üniversitesi Sosyal Bilimler Dergisi, 6(5), 725-733.

Yaylacı, A. F. ve Beldağ, A. (2018). Değerler eğitimi ve güncel tartı̧̧malar: Gazete haberlerine ilişkin bir eleştirel söylem analizi. Sakarya University Journal of Education, 8(1), 139-155.

Yıldırım, A. ve Şimşek, H. (2013). Sosyal bilimlerde nitel araştırma yöntemleri (9.Bask1). Ankara: Seçkin Yayıncılık.

Yin, R. K. (2003). Case study research: Design and methods (3rd ed.). Thousand Oaks, CA: Sage.

Zengin, M. ve Arslan İçöz, E. (2018). Dini, felsefi, psikolojik boyutlarıyla vicdan ve değerler eğitimindeki yeri. Amasya Üniversitesi Ilahiyat Fakültesi Dergisi, O(10), 323-345. DOI: 10.18498/amauifd.379279 
Extended Abstract

\section{The Quest for Value in Turkish Education System: What kind of values are gained through Turkey's renewed Primary Education Curriculum?}

Mehmet KART, Corresponding Author, Lecturer

Kırşehir Ahi Evran University, Faculty of Health Sciences, Kırşehir/Turkey.

mehmetkartt@gmail.com

https://orcid.org/0000-0003-1790-1270

Hüseyin ŞIMŞEK, Professor.

Ahi Evran University, Faculty of Education, Kırşehir/ Turkey.

husimsek@hotmail.com

https://orcid.org/0000-0001-7455-3706

Article Type: Research Article

https://doi.org/10.34234/ded.623787

Received Date: 24.09 .2019

Accepted Date: 15.07 .2020

Published Date: 25.12.2020

\section{Introduction}

Education is one of the basic means of educating people. However, training people requires a policy. For this reason, the question of how to train a human? Consititue the most fundamental pillar of any education policy. When the implementation of the education policy is concerned the curriculum with the education system become significant. In this process, it is necessary to decide what the basic philosophy that guides the curriculum will be and what values will be instilled in the individuals through education. 
The education of values was neglected in a specific period in Turkey, yet it was revived in 2005. This became more evident with the changes made in the Social Studies and Religious and Moral Education curricula (Çelik, 2010, p.2; Kaymakcan \& Meydan, 2011, p.30; Yaylacı \& Beldăg, 2018, p.140). However, instilling values intensively in the curricula was only possible after extensive improvements made in 2017.

There is a strong and dynamic relationship between values and education. Education and educational institutions have important duties regardşng the socialization of new the generations and transferring values to them. Educational Institutions are seen as one of the most effective means of transferring value. Also, what values are to be taught to the children and teenagers in educational institutions is a cross-cutting issue. As societies and cultures have increasingly become heterogeneous. The cultural pluralism starts to complicate the consensus on values. So these changes in values are inevitably reflected in the education system and lead to changes in teaching practices.

In this study, all 20 courses in primary education are analyzed to reveal to what extent the values are reflected in the curriculum. This research is thought to be significant in terms of a comprehensive examination of how values are spread according to teaching stages and lessons. It is hoped that the findings obtained from the study will be beneficial to policy makers, scientists, and teachers.

\section{The Purpose of the Research}

This study aims to reveal the values that are aimed to be taught to the students in the renewed Primary Curriculum in 2017. The following questions will be answered based on the respective purpose:

1. What is the value understanding of Primary Education Curricula?

2. What is the proportional distribution of the intended learning outcomes in the Primary Education Curricula?

3. What are the values included in the curriculum of primary school courses?

4. What is the repetition frequency of the values in the Primary Education Curricula and the related categories of values?

5. What is the distributions of values included in the Primary Curricula according to the courses?

6. What is the relationship between the frequently repeated values and core values in Primary Education Curricula? 


\section{Method}

\section{Research Design}

This study was designed with a qualitative approach and content analysis method was used. This research, which aims to determine the values in the curricula, is also a case study.

\section{Collection of Resources}

The main sources of the research are the curricula of all courses at the primary level published by the Ministry of National Education in 2017. Research reports, dissertations, articles, and electronic documents in the literature related to curriculum and values were used. Documents are important sources of information that should be used effectively in qualitative research (Yildırım \& Şimşek, 2013).

\section{Data Analysis}

The content analysis technique was used in the analysis of the research data. Through the document analysis technique, the written materials are examined, and the ones containing information about the cases are analyzed (Karasar, 2009). In the analysis process, expressions in the form of words, sentences, or paragraphs, thought to be related to the values in the curriculum, were accepted as the analysis unit and value expressions were studied in intended learning outcomes of the curricula. It is aimed to provide integrity by grouping the values which have a similar meaning but expressed differently. In this context, initially, the values specified in the explanations section of the curricula were presented, and then the values in the learning outcomes of the curricula were determined and indicated on the table. The table shows how many different values are included in the outcomes of primary curricula. Then, the coding process was realized in the learning outcomes section that presented in the primary education curricula. With the coding process, both outcomes containing values were determined and it was attempted to find out which values were pointed out in these outcomes. Following the coding process by the researchers, the value categories of the values available in the outcomes of primary education curricula were analyzed. Through the assistance of five experts in the field, the coding reliability method 
was implemented both to determine the value expressions in the outcomes and the categories to which these values are related. Within the scope of encoder reliability, the codings made by the experts were compared and their cohesion was analyzed. Miles and Huberman's (1994) formula [Reliability = number of agreements / total number of agreements + disagreement X 100] was used for coding reliability, and the consistency ratio between coders was $93 \%$. In quantitative analysis, the reliability rate over $80 \%$ is considered as effectual.

\section{Findings}

As a result of the analysis made, it is understood that the renewed Primary Education Curricula in 2017 are based on the desire to bring up good people and good citizens. Besides, healthy, consistent, and balanced personality development of the students, is shown as the aim of value education in the renewed curricula (Türkçe Dersi Öğretim Program1, 2017). In Primary Education Curricula, the multidimensional development of the individual has been emphasized and the importance of values in individual development has been mentioned (Bilişim Teknolojileri ve Yazılım Dersi Öğretim Programı, 2017). Values are among the main priorities of education such as basic life skills and concepts in the organization schema of the curriculum (Hayat Bilgisi Dersi Öğretim Program1, 2017). Under the title "Value(s) Education", the clarifications such as; the reasons for covering values in the curricula, how they are integrated, how they can be transferred to the students in the learning-teaching process, which teaching methods and techniques should be used are included.

\section{Proportional Distribution of Values in Primary Education Gurricula}

According to the findings of the study, $11.83 \%$ of the proposed aqusitions in the curriculum of the 20 courses given at the primary school level contains values. The highest proportional value functions are found in the courses of Games and Physical Activities, Physical Education and Law and Justice. However, no values are included in the learning outcomes that put in Turkish and English curricula.

\section{Values in Primary Curricula, Frequency of Repetition and Related Value Gategories}

65 different values have been included in the curricula of 20 courses at the primary level. The responsibility that is repeated 92 times in primary curricula is 
the most important value. The ten most indicated values except responsibility are; Respect (38 times), Sensitivity for Health (37 times), Justice (26 times) Sensitivity for Cultural Heritage (25 times) and Diligence(25 times), Sensitivity in the Environment (18), Freedom (18), Honesty (16), Being Trustworthy (16) and Patriotism (15). Considering the target group and characteristics of 65 different values available in primary school curricula, they are classified under 9 different value categories as religious-moral, individual, social, national, democratic, scientific, economic, environmental, and aesthetic. Through these classifications, it is understood that the most important value in the curricula is social values and 14 different values under this category have been repeated 200 times. This is followed by individual values repeated 154 times. The least repeated categories of values in primary curricula are aesthetic (14), economic (8), and scientific (theoretical) (8) values.

\section{Comparison of Frequent Repetitive Values and Core Values in Pri- mary Curricula}

It has been indicated that the core values that the Ministry of National Education gives importance correspond with the intended learning outcomes in the primary education curricula. However, the core values such as self-control (1), love (5), and friendship (7) are limited in the section of learning outcome of primary education curricula. On the other hand, values such as sensitivity in healthcare (37), diligence (25), and sensitivity in cultural heritage (25) which are not in the list of core values are frequently repeated in the intended learning outcome section of different courses.

\section{Results And Discussion}

Based on the indications of the research, it is understood that there is a special emphasis on values and values education in 2017 primary education curricula compared to previous curricula. In the introduction part of the curriculum, the subject of values is put under a separate title. In renewed primary education curricula, there are many intended learning outcomes related to the affective domain, including values. It is stated in the curricula that educational institutions should form their aims based on education and education should be considered as an activity formed within value education (Türkçe Dersi Öğretim Programı, 2017). The philosophy of value in primary education curricula published by the Ministry is based on the understanding of raising good people and good 
citizens (Bilişim Teknolojileri ve Yazılım Dersi Öğretim Programı, 2017). On the other hand, when the organizational structure of 2017 primary education curricula is analyzed, it is understood that values are already in the mainframe of the curriculum. In the curriculum, values are placed in the main priorities of education such as basic life skills and concepts (TTKB, 2017). Core values that are expected to be acquired by students are presented as an innovation in 2017 curricula. The values of justice, friendship, honesty, self-control, patience, respect, love, responsibility, patriotism, and benevolence are stated as core values in the curricula (Hayat Bilgisi Dersi Öğretim Program1, 2017). When we look into the classification of core values, Social (justice, friendship, honesty, respect, and benevolence), personal (self-control, patience, responsibility, love) and national (patriotism) values are prominent. $11.83 \%$ of the learning outcomes of the curriculum at the primary education level contain values. In terms of lessons, the highest function of value is included in Game and Physical Activities, Physical Education, and Law and Justice Courses. However, there are no functions in value in Turkish and English curricula. In terms of value diversity, the most different value expressions are found in the Physical Education course. According to the results of the research findings, 65 different values were included in the curricula of 20 courses at the primary level. In primary curricula, the most important value is responsibility. The ten other values that considered to be significant are; respect, sensitivity in health care, justice, sensitivity in cultural heritage, diligence, sensitivity in environment, freedom, honesty, being trustworthy, and patriotism. When we compare the most repeated values and core values in the entire curricula, it is seen that there are similarities to some extent. Values in the 2017 primary education curricula are grouped under nine different value categories: religious-moral, individual, social, national, democratic, scientific, economic, environmental, and aesthetic. This classification is highly similar to classifications found in the related literature. The findings of the research show that the renewed primary education curricula in 2017, aim to educate individuals in a multidimensional way and to realize that purpose, it gives importance to instill attitudes and behaviors related to different value categories. Considering the repetition frequency of values that contained in the intended learning outcomes of the 2017 primary education curricula, it is seen that there is an understanding that prioritizes individual and social values. 